\title{
Recent Development of Social Simulation as Reflected in JASSS between 2008 and 2014: A Citation and Co-Citation Analysis
}

\author{
Jonas Hauke', Iris Lorscheid ${ }^{1}$, Matthias Meyer ${ }^{1}$ \\ 1/nstitute of Management Accounting and Simulation (MACCS), Hamburg University of Technology, Am \\ Schwarzenberg-Campus 4, 21073 Hamburg, Germany \\ Correspondence should be addressed tomatthias.meyer@whu.edu \\ Journal of Artificial Societies and Social Simulation 20(1) 5, 2017 \\ Doi: 10.18564/jasss.3238 Url: http://jasss.soc.surrey.ac.uk/20/1/5.html \\ Received: 17-06-2016 Accepted: 07-10-2016 Published: 31-01-2017
}

\begin{abstract}
The research field of social simulation comprises many topics and research directions. A previous study about the early years indicated that the community has evolved into a differentiated discipline. This paper investigates the recent development of social simulation as reflected in Journal of Artificial Societies and Social Simulation (JASSS) publications from 2008 to 2014. By using citation analysis, we identify the most influential publications and study the characteristics of citations. Additionally, we analyze the development of the field with respect to research topics and their structure in a co-citation analysis. The citation characteristics support the continuing highly multidisciplinary character of JASSS. Prominently cited are methodological papers and books, standards, and NetLogo as the main simulation tool. With respect to the focus of this research, we observe continuity in topics such as opinion dynamics and the evolution of cooperation. While some topics disappeared such as learning, new subjects emerged such as marriage formation models and tools and platforms. Overall, one can observe a maturing inter- and multidisciplinary scientific community in which both methodological issues and specific social science topics are discussed and standards have emerged.
\end{abstract}

Keywords: Social Simulation, Lines of Research, Multidisciplinary, Citation Analysis, Co-Citation Analysis

\section{Introduction}

1.1 Social simulation is considered to be a multidisciplinary and rapidly developing field Meyer et al.,2009;, Squazzoni et al. 2014). This is mirrored by increasing citations in different ISI- and Scopus-indexed sources (Squazzoni 2010) and by the fact that simulation methods have more recently gained a foothold in different social science publication outlets (Fioretti 2013; Leitner \& Wall 2015, Secchi \& Seri 2016). Nevertheless, the Journal of Artificial Societies and Social Simulation (JASSS) remains one of the major publication outlets for research in social simulation Secchi \& Seri|2016, Squazzoni 2010, Squazzoni \& Casnici|2013).

1.2 In 2014, JASSS experienced a significant change that led to intensive discussions about the journal. After 17 years, Nigel Gilbert, the founder of the journal, handed over his responsibilities as editor, which resulted in a debate in the social simulation community about the future direction of JASSS (see e.g., SimSoc 2015). This discussion addressed the scope of the journal and its possible future direction. Some perceive JASSS as an interdisciplinary journal at the intersection of various fields such as the social, behavioral, and computational sciences, whereas others suggest that the journal's scope should be extended to include more fundamental questions of science that support simulation research in general. Another group points out that JASSS frequently publishes technical, epistemological, and methodological papers. This discussion shows the different perspectives on the journal and its role in the community.

1.3 This diversity might also be due to the multidisciplinary and dynamic character of JASSS, which makes it even more challenging to get an overview of the journal, the related fields of social simulation, and the recent development of both. Such an overview, however, would be beneficial for several reasons. First, it would allow for an empirical basis for the above-described discussions about the past and future direction of JASSS. Second, 
given the increasing interest from other disciplines, it would make access to the field much easier, as newcomers could inform themselves about the current state of the literature. Of particular relevance for this would be a summary of the most influential articles and main foci of research. Finally, such an overview would complement a previous study about the development of the field in the early years, from its beginning in 1998 until 2007 Meyer et al. 2009). In combination, the two may provide an overview of the whole time span of the first 17 years of JASSS under the editorship of Nigel Gilbert and the field during that time.

1.4 The objective of this paper is to provide such an overview. We map the recent developments in the field of social simulation as reflected in JASSS publications from 2008 to 2014. This study focuses on developments regarding the most cited sources and on networks of frequently co-cited publications. Bibliometric methods such as citation and co-citation analysis are suitable to uncover hidden patterns in publication outlets. These patterns delineate historical developments, depict the current situation, and provide a foundation to discuss future developments (Van Raan 2014).

1.5 In terms of the methods used, we closely link our work to a previous study of the development of JASSS in its first 10 years (Meyer et al. 2009), which allows us to identify continuities as well as changes. We particularly want to investigate the following issues: (1) What are the recent developments in view of cited publications, types of citation sources, or influences of certain fields? Does more recent development differ from that in the first 10 years and in what respect? (2) Which co-citation networks emerged, how strong are their relations, and to what research topics are these related? (3) Are trends observable, in the past seven years or the overall time span of 17 years? Are there indicators for the future direction of the journal and social simulation as a discipline?

1.6 The paper is organized as follows. In the next section, we describe our method and data set Afterwards, we present the most influential publications in JASSS and highlight some specific source characteristics regarding publication age, source type, and cited journals classified by discipline. Subsequently, we present our results of the co-citation analysis to identify research clusters in JASSS and investigate the relationships between these clusters. Further, we present a longitudinal analysis of the research topics in social simulation. Finally, we draw some conclusions and make suggestions for future research.

\section{Method}

2.1 This paper investigates the development of the intellectual structure of JASSS from 2008 to 2014 . To14 this end, we apply the bibliometric methods of citation and co-citation analysis. Both methods are established for the analysis of scientific fields (Osareh $1996 \mathrm{a} \mid \mathrm{b})$ and have been successfully applied to the analysis of different journals (Meyer et al. 2009. 2011:| Mustafee et al. 2014a b b Squazzoni \& Casnici|2013). To maximize comparability with the previous study, we mainly follow the methods applied in Meyer et al.(2009), but extend them to explore additional questions.

2.2 Citation analysis investigates the occurrences of referenced publications. Via citations, an author shows the relation between the own work and the work of other scholars (Osareh 1996a). Whilst the number of citations is generally considered to be an indicator of the degree of a study's perceived relevance and influence Bornmann \& Daniel 2008, Radicchi \& Castellano 2012), citation counts also have weaknesses. Studies of citation behavior show that scientists not only cite other work to acknowledge the intellectual or cognitive influence of scientific peers, but also for other, probably less scientific reasons, which are individual and different Bornmann \& Daniel 2008. Furthermore, so-called "sleeping beauties", which are publications whose importance is not recognized for several years after publication, may remain undiscovered Ke et al. 2015). Still, citations are an indicator to determine the influence of publications and thus are commonly used evaluation measures.

2.3 Co-citation analysis examines the relationships between cited publications. A co-citation means that two publications are cited in the same document. For example, citation A and citation B are co-cited if both publications are listed in the same reference list of article $\mathrm{C}$. The number of co-citations among publications is regarded as an indicator of their proximity Gipp \& Beel 2009 Small 1973]. The identified relationships between cited publications allow us to draw conclusions about the internal structure of research, based on the resulting clusters of publications.

2.4 Using absolute citation values is not suitable to generate clearly defined clusters of publications. Sources with a high number of citations tend to appear more frequently in clusters than less cited sources due to their wide dissemination. To address this problem, several scaling methods have been developed. Gmür 2003) evaluated established methods and suggested a measure called a CoCit score, which sets the squared co-citation count in relation to the minimum and mean counts of two individual citations A and B Gmür|2003).

$$
\operatorname{CoCit}_{A B}=\frac{\left(\text { co-citation }_{A B}\right)^{2}}{\operatorname{minimum}\left(\text { citation }_{A} ; \text { citation }_{B}\right) * \text { mean }\left(\text { citation }_{A} ; \text { citation }_{B}\right)}
$$




\begin{tabular}{lccccc}
\hline & \multicolumn{2}{c}{ Meyer et al. (2009) } & \multicolumn{2}{c}{ This study } & Both \\
& $1998-2002$ & 2003-2007 & 2008-07/2011 & 08/2011-2014 & 1998-2014 \\
\hline Number of articles & 110 & 184 & 133 & 165 & 592 \\
Number of citations & 2873 & 5375 & 4583 & 6191 & 19022 \\
Average articles per issue & 5.58 & 9.15 & 9.47 & 12.00 & 8.76 \\
Average citations per article & 26.12 & 29.21 & 34.46 & 37.52 & 32.13 \\
Average source age (years) & 10.85 & 10.91 & 12.20 & 12.61 & 11.77 \\
\hline
\end{tabular}

Table 1: Overview of the data sets of both studies: articles and citations (1998-2014)

2.5 In this paper, we apply this well-established measure to calculate the strength of co-citations in JASSS (see also Allmayer \& Winkler 2013; Backhaus et al. 2011, García-Lillo et al. 2016, Greene et al.|2008; Moqri et al. 2011). To reduce the complexity of analysis, we focus on the most cited publications, only including those with at least three co-citations. Further, we set a minimum CoCit score value of 0.25 as the threshold (both in line with Meyer et al.2009). As a result, groups with distinguishable network topologies emerge such as isolated pairs, trees, mesh, and fully connected clusters. In this paper, we refer to a cluster if a network contains at least three sources linked by at least three co-citation relationships, with CoCit scores greater than or equal to 0.25 (as in Meyer et al. 2009.

2.6 For the data set generation, we used the online index of JASSS articles. This index provides an open access database to all articles and their references ${ }^{1}$. We gathered the data by parsing ${ }^{2}$ all journal articles published in JASSS between 2008 and 2014, excluding book review articles. The parser retrieved the associated lists of references in a CSV file and assigned each source an ID. Identical sources were assigned the same ID. We corrected parser bugs and data inconsistencies manually ${ }^{3}$. Afterwards, we were able unambiguously to verify citations as duplicates. If necessary, we corrected the source IDs and frequency of citations by hand. We used the resulting data set for the citation analysis and proceeded with the calculation of symmetric reference-reference matrices for the co-citation analysis, in line with the description of Zhang et al. (2009).

\section{Data Set}

3.1 The resulting data set forms the basis for the citation and co-citation analysis. First, we want to provide some descriptive statistics. This comprises the number of JASSS articles included as well as the publications referenced in these articles. Table 1 shows the data set for 1998-2014. The whole time span of 17 years is included in the table to compare the results of our study with the results from the previous study (Meyer et al. 2009).

3.2 The first study investigated two time periods, 1998-2002 and 2003-2007. In this study, we address the subsequent years from 2008 to 2014 and divide these seven years into two periods of 3.5 years ${ }^{4}$. This is driven by the motivation to create comparable time periods âĂŞ in terms of the number of analyzed articles and citations âĂŞ to the previous study. The number of JASSS articles increased over time per issue and year from 133 articles in the first period of this study to 165 articles in the second period. The overall increase in the number of articles and citations is also reflected in the average number of articles per issue. JASSS issues of later periods include more articles than issues in the early years (see, for example, an average number of 11.8 articles per issue in the last period compared with 9.5 articles per issue in the period before). Even though the recent periods are shorter, their number of citations is comparable with the two periods of the previous study.

3.3 To deal with the rise in scientific publications, we determine the growth rate for the domain of social simulation and incorporate that with regard to the split of the data sets. First, we consider the general rise in scientific publications. This trend was identified as corresponding to a doubling of the global number of references in scientific publications within 12 years (Pan et al. 2016). Some scholars come up with effective indices to discount exponential growth for selected domains (e.g., Parolo et al.2015). Nevertheless, deflation indices are dependent on research domains and average indices neglect the heterogeneity within and across disciplines. Following our assumption that social simulation is at least partially reflected in JASSS, we determined its growth rate by analyzing the yearly number of citations in JASSS (see Figure 1). Given our data set, we assumed an exponential function and identified an $8.5 \%$ growth rate of references per year $\left(R^{2}=0.76\right)$. This growth rate is above average in relation to the growth rate of $5.8 \%$ for all domains, and remarkably higher than $4.8 \%$ for the social sciences (Pan et al. 2016).

3.4 To understand this result, we consider the two parameters that determine the growth rate: the increasing number of publications and the increasing average number of references per publication. As previously mentioned, 


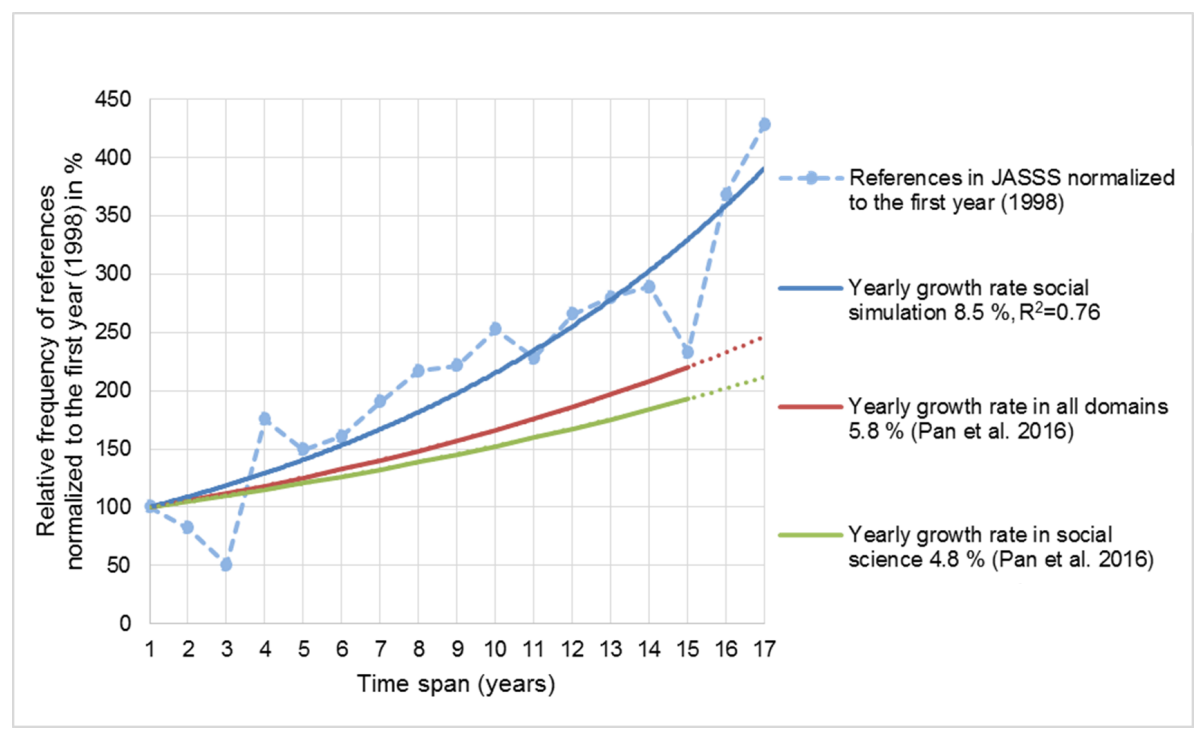

Figure 1: Social simulation growth rate reflected in JASSS for 17 years (1998-2014) in comparison to other domains.

the social simulation growth rate is also driven by both parameters. We identify an increasing number of articles in JASSS as well as higher numbers of references. Overall, the comparable high growth rate indicates fast growth.

3.5 The growth rate of references influences the comparability of citation metrics in different time spans. Average growth and deflation or inflation rates are metrics to reflect trends. Definite rates are per se not retrievable considering that references are commonly made in discrete time intervals of years. Given the calculated social simulation growth rate of $8.5 \%$, a six-year time span (2008-2013) would be the most statistically comparable time span to the previous study (1998-2007) to come to comparable data set sizes. Following our aim to cover the full time span of the editorship of Nigel Gilbert, we cover a seven-year time span in this study (2008-2014) and accept a slight distortion. A division of the seven-year time span by growth rate approximately results in a four-year (2008-2012) and a three-year (2012-2014) period. Nevertheless, we slightly deviate from this and use equal periods of 3.5 years, on the grounds that an uneven split of the recent time span would dilute the tangibility of comparison. Finally, we account for the growth rate at a higher aggregation level. The previous study covers ten and our study a shorter time span of seven years.

3.6 Looking at the citation characteristics, we identify that the average source age increased from 1998 to 2014 . This effect can be ascribed to the fact that some fundamental work is still cited in more recent publications. To visualize this, we plotted the publication years of the cited publications in JASSS per time period (see Figure22. The distribution graph shows a typical shape found in other fields as well, and could be approximated by a left-skewed distribution (see e.g., Schäffer et al.|2011).

3.7 Next, we investigate the frequency of citations. The repeated occurrence of citations in JASSS articles is the basis for our citation and co-citation analysis. The overview in Table 2 shows the number of citations that occur once, twice, or at least three times. Most publications are only cited once, while only about $10 \%$ of the references occur multiple times. Compared with the previous study, the relative frequency of single citations increased from about $88 \%$ to more than $91 \%$ in the most recent period (Meyer et al.|2009). This indicates slightly increasing diversification in terms of sources.

3.8 Citations that occur at least three times represent the data set for the co-citation analysis. We identify on average 145.5 citations that occur at least three times per classified time period in JASSS. Regarding this measure, the two time spans (10 years vs. 7 years) of the studies are comparable. Within these time spans, however, only the two recent periods are similar in view of the number of citations that occur more than three times (136 and 141). We see an imbalanced distribution of 95 citations vs. 210 citations within the first time span of the previous study. This also results in a denser co-citation network for the second period of the first study (Meyer et al. 2009. 


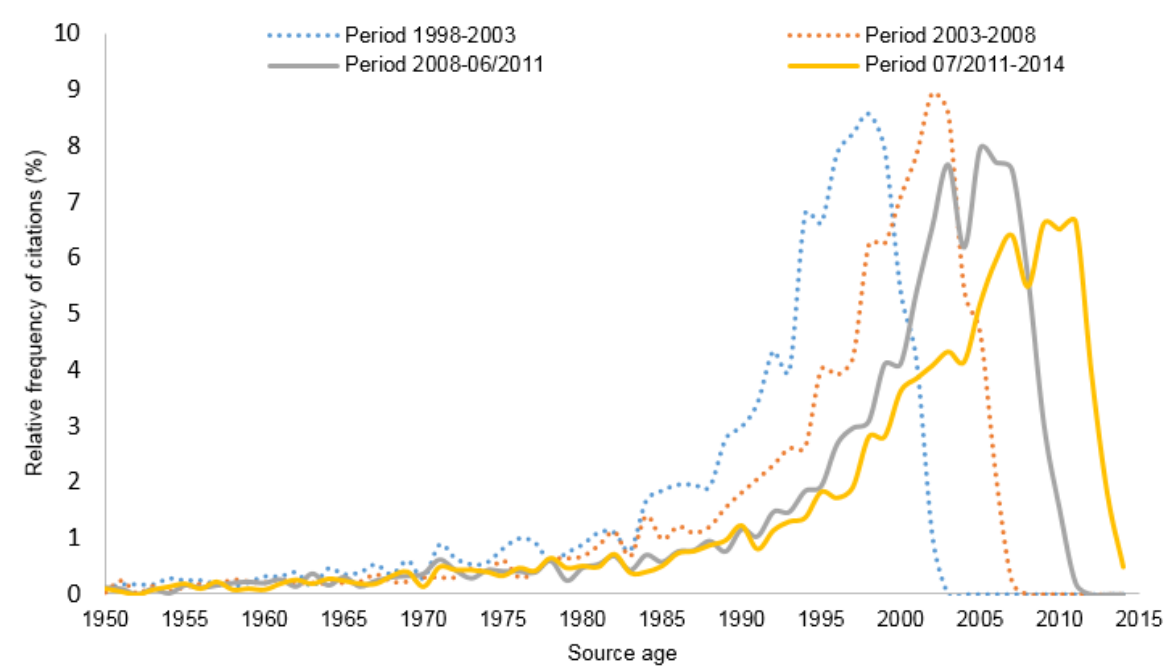

Figure 2: Source age of cited publications in JASSS from 1998 to 2014.

\begin{tabular}{|c|c|c|c|c|c|c|c|c|c|c|c|c|}
\hline \multirow[b]{3}{*}{$\begin{array}{l}\text { Freq. of citation oc- } \\
\text { currence }\end{array}$} & \multicolumn{6}{|c|}{ Previous study (Meyer et al. 2009) } & \multicolumn{6}{|c|}{ This study } \\
\hline & \multicolumn{3}{|c|}{ 1998-2002 } & \multicolumn{3}{|c|}{$2002-2007$} & \multicolumn{3}{|c|}{$2008-07 / 2011$} & \multicolumn{3}{|c|}{ 08/2011-2014 } \\
\hline & $\begin{array}{l}\text { Abs. } \\
\text { freq. }\end{array}$ & $\begin{array}{l}\text { Rel. } \\
\text { freq. } \\
(\%)\end{array}$ & $\begin{array}{l}\text { Cum. } \\
\text { freq. } \\
(\%)\end{array}$ & $\begin{array}{l}\text { Abs. } \\
\text { freq. }\end{array}$ & $\begin{array}{l}\text { Rel. } \\
\text { freq. } \\
(\%)\end{array}$ & $\begin{array}{l}\text { Cum. } \\
\text { freq. } \\
(\%)\end{array}$ & $\begin{array}{l}\text { Abs. } \\
\text { freq. }\end{array}$ & $\begin{array}{l}\text { Rel. } \\
\text { freq. } \\
(\%)\end{array}$ & $\begin{array}{l}\text { Cum. } \\
\text { freq. } \\
(\%)\end{array}$ & $\begin{array}{l}\text { Abs. } \\
\text { freq. }\end{array}$ & $\begin{array}{l}\text { Rel. } \\
\text { freq. } \\
(\%)\end{array}$ & $\begin{array}{l}\text { Cum. } \\
\text { freq. } \\
(\%)\end{array}$ \\
\hline 1 & 2078 & 87.94 & 87.94 & 3765 & 87.33 & 87.33 & 3441 & 89.82 & 89.82 & 4921 & 91.64 & 91.64 \\
\hline 2 & 190 & 8.04 & 95.98 & 336 & 7.79 & 95.13 & 254 & 6.63 & 96.45 & 308 & 5.74 & 97.37 \\
\hline$\geq 3$ & 95 & 4.02 & 100.00 & 210 & 4.87 & 100.00 & 136 & 3.55 & 100.00 & 141 & 2.63 & 100.0 \\
\hline $\begin{array}{l}\bar{N} \text {. different citation } \\
\text { sources }\end{array}$ & & & 2363 & & & 4311 & & & 3831 & & & 5370 \\
\hline
\end{tabular}

Table 2: Frequency of citations in JASSS from 2008 to 2014

\section{Results of the Citation Analysis}

4.1 The citation analysis identifies the most cited sources and their characteristics, such as the external publication sources acknowledged in JASSS and corresponding disciplines. We extract the most common sources from the data set for both periods. Table 3 ranks the most cited sources in descending order ${ }^{5}$. In addition, the relative citation value is calculated as the number of citations divided by the number of JASSS articles published in the corresponding time period. Moreover, we classify the types of sources into books, journal articles, web pages, and proceeding papers.

4.2 The results show three standard books that are cited frequently in both periods: Axelrod's The Evolution of Cooperation (2006), Epstein and Axtell's Growing Artificial Societies (1996), and Gilbert and Troitzsch's Simulation for the Social Scientist 2005$)^{6}$. In the second period, Nigel Gilbert's (2008) Agent-Based Models appeared. This book became the third most cited source with 11 citations in the second period, and thereby superseded the highly cited books of Axelrod 2006 and Epstein \& Axtell (1996. With the exception of the top three most cited sources, the majority of cited sources are journal articles. It is remarkable that in both periods, six articles were published in JASSS itself.

4.3 The NetLogo website became the most referenced source in JASSS with 25 citations. In comparison to the first period, the relative citation value of NetLogo doubled to 15.2\%. To understand the reason for citing this source better, we investigated the context in which these 25 NetLogo citations occurred. Twenty articles use NetLogo as a simulation platform for their simulation studies, and the remaining five articles have a clear methodological focus on agent-based modeling and related tools Bersini|2012, Le Page et al. 2012; Schwarz et al. 2012, Thiele et al. 2012,2014). Thus, one can conclude that the simulation tool NetLogo is used in at least $12 \%$ of the studies recently published in $\mathrm{JASSS}^{7}$.

4.4 In addition, there are indicators of another standard that may emerge for agent-based models. In particular, the Overview Design Details (ODD) protocol (Grimm et al. 2006) as well as its review and first update 


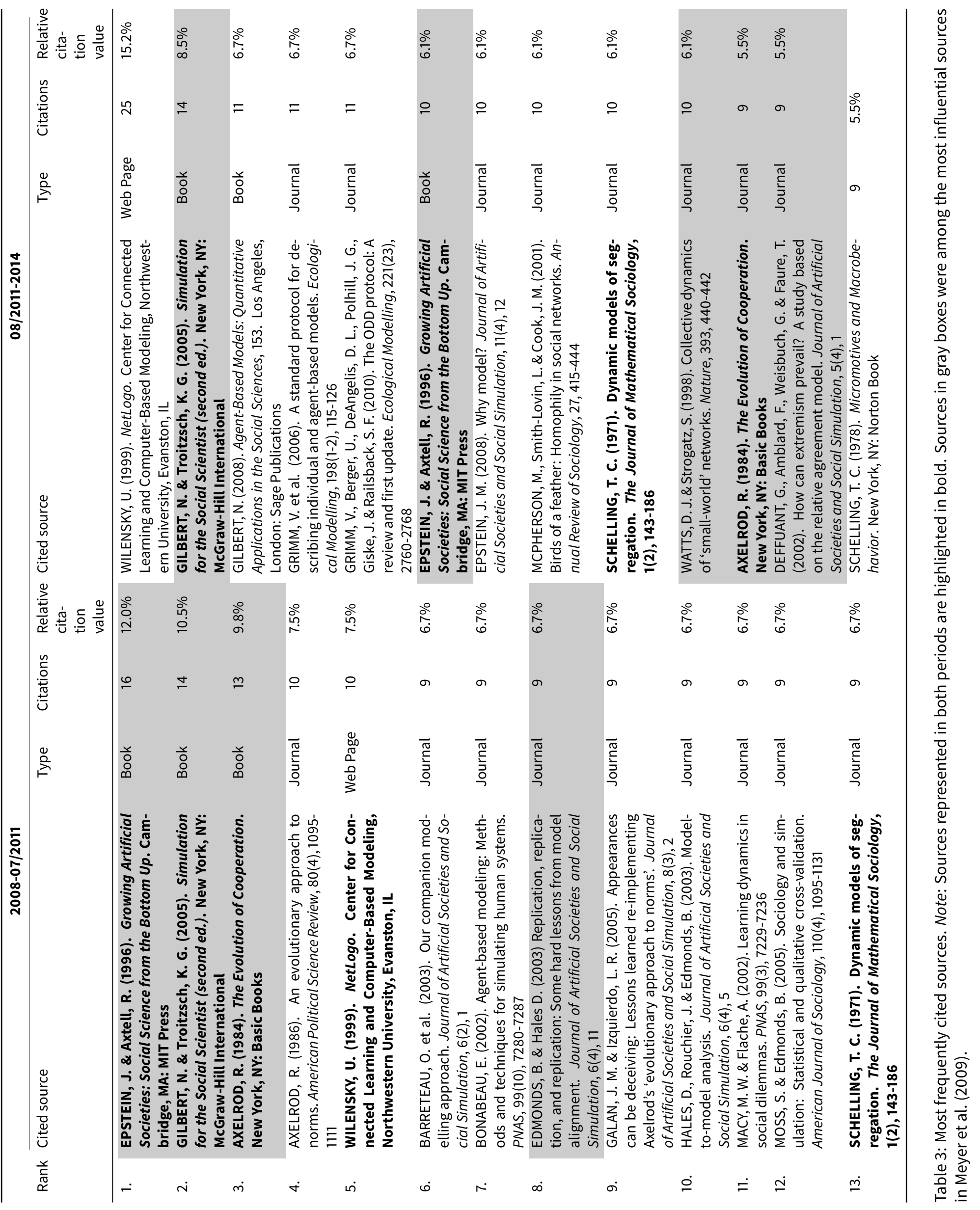




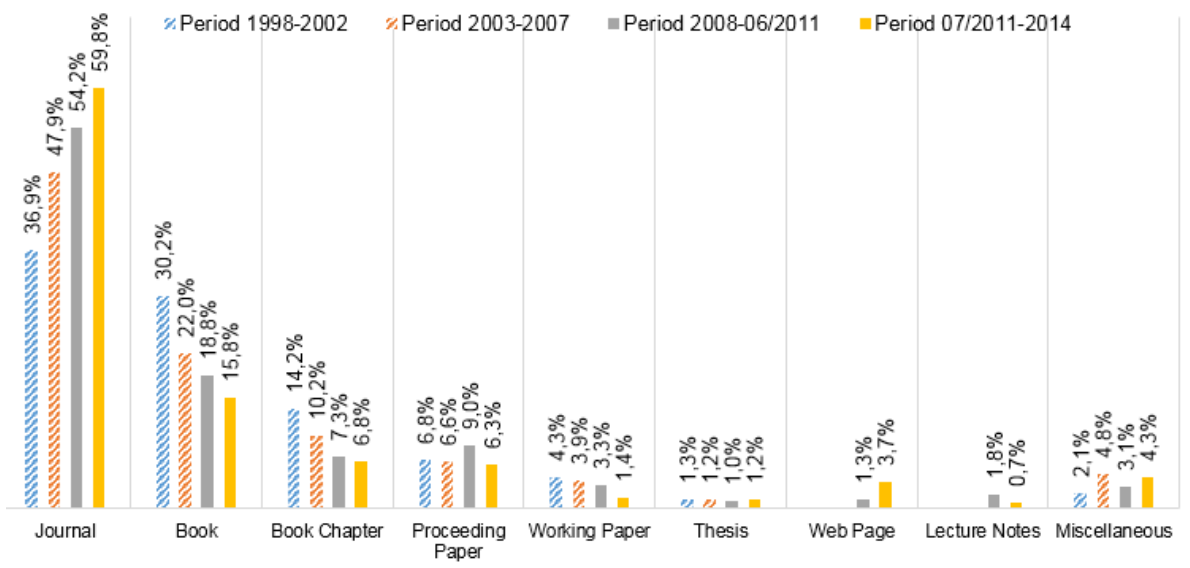

Figure 3: Types of sources cited in JASSS from 1998-2014.

Grimm et al. 2010 has $6.67 \%$ relative citations in the second period. This protocol provides a framework with which to specify and communicate agent-based models (Railsback \& Grimm 2011).

4.5 We further investigate the types of sources cited in the two periods (see Figure 3). To this end, we classify the citations into nine categories: journal, book, book chapter, proceeding paper, lecture notes, working paper, thesis, web page, and miscellaneous ${ }^{8}$. The trend reported in the previous study towards more journal article citations continues. In the recent period, 59.8\% of the total citations are journal publications, which reflects a continuous increase compared with $36.9 \%$ for the first period. Correspondingly, the number of book and book chapter citations declined over time. This also indicates that more relevant journal publications exist that specialize in topics around social simulation, which again hints at a maturation of the field.

4.6 In the previous study, web pages were part of the category "miscellaneous", but in the subsequent years they have become more cited. For this reason, we introduced "web page" as a new distinct category. Regarding the most cited sources, the increasing percentage of web citations basically results from the acknowledgement of simulation tools such as NetLogo, Repast, and Swarm, which are provided as open-source software via web pages. Articles consequently cite web pages that use these tools. In addition, a number of methodological papers compare simulation methods and tools by referencing the corresponding web pages.

4.7 Finally, we investigate whether the multidisciplinary nature of social simulation observed by Meyer et al. 2009. is supported by our citation data. To this end, we identify the 15 most frequently cited journals and their relative citation values based on the total number of 6,197 journal citations between 2008 and 2014 (see Table 4). The ranking shows ten journals, which are represented in both time spans, which may indicates certain stability. Nevertheless, the impact of many journals changed.

4.8 JASSS itself is still by far the most cited journal (11.2\%). This result is in line with other self-citation rates of journals, which are about 12\% (Thomson Reuters 2002. The second and third most cited journals are Nature $(2.6 \%)$ and Science (1.9\%). The list again provides evidence of the multidisciplinary nature of JASSS. The referenced journals cover a broad field of research disciplines among natural scientific journals (e.g., Physica A, Physical Review E, Journal of Theoretical Biology, and Ecological Modeling, social science and economic journals (e.g., American Journal of Sociology and American Economic Review), and a journal related to psychology (Journal of Personality and Social Psychology).

4.9 Against the background that the number of journal citations increased, we expect that journal citations are diverse. We applied the Herfindahl-Hirschman Index ( $\mathrm{HHI})$ to provide a concentration measure for journal citations (Schmalensee 1977), which has already been applied in other bibliometric studies (e.g., Chi 2016). Considering the number of journals $(N)$, the share of a journal based on citations $\left(x_{i}\right)$, and the arithmetic average of the shares $X$, the $\mathrm{HHI}$ is calculated as follows:

$$
H H I=\sum_{i=1}^{N}\left(\frac{x_{i}}{N * X}\right)^{2}
$$

4.10 The result of the index is proportional to the average market share, and ranges from $1 / \mathrm{N}$ to 1 . A higher index indicates a concentration of citations. Including the journal citations in the first time span (1998-2007: $\mathrm{N}=3560)$ and the journal citations in the second time span (2008-2014: $\mathrm{N}=6093)$, the HHIs result in 1.45\% and 1.59\%, respectively, which indicates a concentration of journal publications. This result is contractionary to our expectation 


\begin{tabular}{|c|c|c|c|}
\hline \multicolumn{2}{|r|}{ Journal Rank 1998-2007 (Meyer et al. 2009) } & \multicolumn{2}{|r|}{ Journal Rank 2008-2014 } \\
\hline 1 & $\begin{array}{l}\text { Journal of Artificial Societies and Social Simu- } \\
\text { lation }(9.1 \%)\end{array}$ & 1 & $\begin{array}{l}\text { Journal of Artificial Societies and Social Simu- } \\
\text { lation }(11.2 \%)\end{array}$ \\
\hline 2 & Nature $(2.4 \%)$ & 2 & Nature $(2.6 \%)$ \\
\hline 3 & American Economic Review (2.0\%) & 3 & Science $(1.9 \%)$ \\
\hline 4 & Science $(1.9 \%)$ & 4 & Ecological Modelling (1.3\%) \\
\hline 5 & American Journal of Sociology (1.8\%) & 5 & Physica A (1.2\%) \\
\hline 6 & Physical Review E (1.6\%) & 6 & Physical Review E (1.2\%) \\
\hline 7 & Physica A (1.5\%) & 7 & American Journal of Sociology (1.1\%) \\
\hline 8 & Artificial Intelligence (1.4\%) & 8 & Journal of Theoretical Biology (1.0\%) \\
\hline 9 & American Sociological Review (1.1\%) & 9 & American Economic Review (1.0\%) \\
\hline 10 & $\begin{array}{l}\text { Journal of Personality and Social Psychology } \\
(1.1 \%)\end{array}$ & 10 & Management Science (0.9\%) \\
\hline 11 & Complexity $(1.0 \%)$ & 11 & $\begin{array}{l}\text { Computational and Mathematical Organization } \\
\text { Theory }(0.9 \%)\end{array}$ \\
\hline 12 & $\begin{array}{l}\text { Computational and Mathematical Organization } \\
\text { Theory }(1.0 \%)\end{array}$ & 12 & $\begin{array}{l}\text { Journal of Personality and Social Psychology } \\
(0.8 \%)\end{array}$ \\
\hline 13 & $\begin{array}{l}\text { Journal of Economic Dynamics and Control } \\
(1.0 \%)\end{array}$ & 13 & Ecology and Society $(0.8 \%)$ \\
\hline 14 & Journal of Political Economy (0.9\%) & 14 & American Sociological Review (0.7\%) \\
\hline 15 & The Quarterly Journal of Economics $(0.8 \%)$ & 15 & Journal of Conflict Resolution (0.7\%) \\
\hline
\end{tabular}

Table 4: The top 15 most frequently cited journals in JASSS from 1998 to 2014. Note: Journals represented in both time spans are highlighted in gray.

of diversification as well as to the fact that $\mathrm{N}$ increases remarkably. The $\mathrm{HH}$ is not invariant to $\mathrm{N}$, as a greater $\mathrm{N}$ usually decreases the index. To examine this phenomenon further, we excluded the self-citations of JASSS and recalculated the index. This result shows diversification, with an $\mathrm{HHI}$ of $0.63 \%$ for the first time span and $0.44 \%$ for the second time span ${ }^{9}$. Thus, the external environment of JASSS diversifies in terms of cited publications outside JASSS, while the high number of self-citations in JASSS points to concentration.

4.11 To investigate the multidisciplinary character of JASSS further, we classify all cited journals into subject fields. We conduct the classification by using the list "Essential Science Indicators Subject Areas" provided by Thomson Reuters 2016$]^{10}$. The list classifies 27,208 journals into a subject field, but some journals cited in JASSS are not covered. No category is assigned to $15.4 \%$ of the journals cited in the first time period and $15.2 \%$ in the second time period. JASSS is recorded in the category "social science, general". However, self-references of JASSS are excluded from the analysis in order to focus on the outgoing citations that unambiguously reflect the journal environment.

4.12 Based on journal citations, the impact of different subject fields on JASSS is shown in Figure 4 Recently, the category "social science, generalâĂi occurred at the top of the list. In both time spans, most journals can be classified into the categories "social science, general" and "economics \& business". The category "psychiatry/psychology" remains the third most influential category. The decreasing influence of computer sciencerelated journals is noticeable, while journals classified as "environment/ecology" gained more impact".

4.13 The diversity of cited journals and subject fields supports JASSS's self-description as an "interdisciplinary journal for the exploration and understanding of social processes by means of computer simulation" (JASSS 2015). Given its orientation to the method of computer simulation, however, one may expect a stronger acknowledgement of journals in the discipline of computer science (Wellman 2014). However, this assumption is not reflected in the results. The methods of computer simulation are rather briefly referenced by authors. This can be ascribed to the fact that simulation concepts are also partially developed within social sciences (Davidsson 2002). This is different for the externally addressed research topics, mainly related to social science and economics and business.

4.14 Overall, the results of the citation analysis empirically support the dynamic and interdisciplinary character of social simulation. Moreover, the shift in publication outlets towards journals continues, which was considered to be an indicator for maturation in the previous study (Meyer et al. 2009). This indication is further supported in this study by the more frequent use of certain tools and standards. 


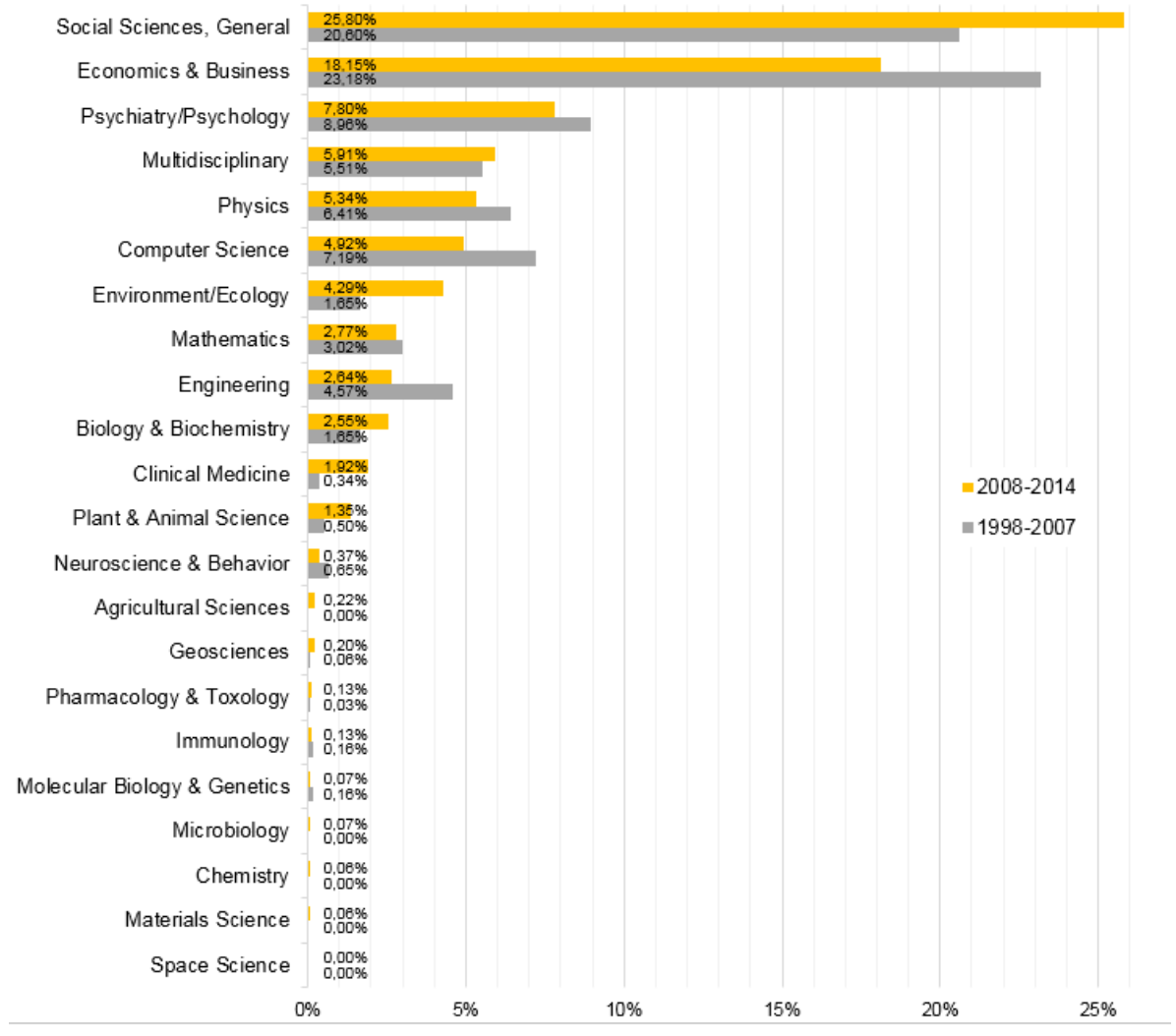

Figure 4: Thomson Reuters subject fields and their impact on JASSS based on journal citations normalized to 1998-2007.

\section{Results of the Co-Citation Analysis}

5.1 While the citation analysis gives a first impression of the development in the academic community, the cocitation analysis uncovers the structure and interrelations within a discipline. By using a co-citation analysis, we identified clusters and distinct groups within them. All nodes and links that belong to a distinct group are numbered and colored ${ }^{12}$, and these groups typically represent subfields and specific research streams in the discipline. Figure 5 depicts the results of the co-citation analysis for the period from 2008 to $07 / 2011$. The network has a density of 0.044 and is composed of 368 links and 92 nodes. It consists of two clusters: cluster (1) that comprises seven groups and a separated cluster (2) that consists of a single group.

5.2 At the center of the first cluster is the group (1.1) Learning in Social Dilemmas ${ }^{13}$. The hub of this cluster is the publication by Izquierdo et al. (2008) entitled "Reinforcement Learning Dynamics in Social Dilemmas", with nine links. The group is composed of 15 nodes, 84 links, and has a density of $0.4^{14}$. It is the most connected group within the surrounding groups and is centrally located in the first cluster.

5.3 Next, we find two basic classes of topics in this cluster: Social science-related topics and methodologicaloriented topics. The groups (1.2) Norms and (1.7) Evolution of Cooperation represent social science topics such as group (1.1) Learning in Social Dilemmas. Topic (1.5) Environmental Aspects is rather separated. The other groups are related to methodological aspects in social simulation, namely (1.3) Modeling, (1.4) Validation, and (1.6) Replication.

5.4 The second cluster represents the topic (2) Opinion Dynamics, which can also be classified as related to social sciences. Five topics (Opinion Dynamics, Learning in Social Dilemmas, Norms, Modeling, and Environmental Aspects) have already been identified in the previous study (Meyer et al. 2009). We identify many connected groups in this period. General topics such as Learning, Validation, Replication, and Modeling are relevant for all simulation studies, and thus are acknowledged from many perspectives.

5.5 In the most recent period (08/2011 to 2014), we observe a process of differentiation (see Figure 6), and identify six clearly separated clusters and eight groups. This network has a slightly higher density of 0.047 , including 297 links and 80 nodes in comparison with the earlier network (2008 to 07/2011). Nevertheless, the groups in 


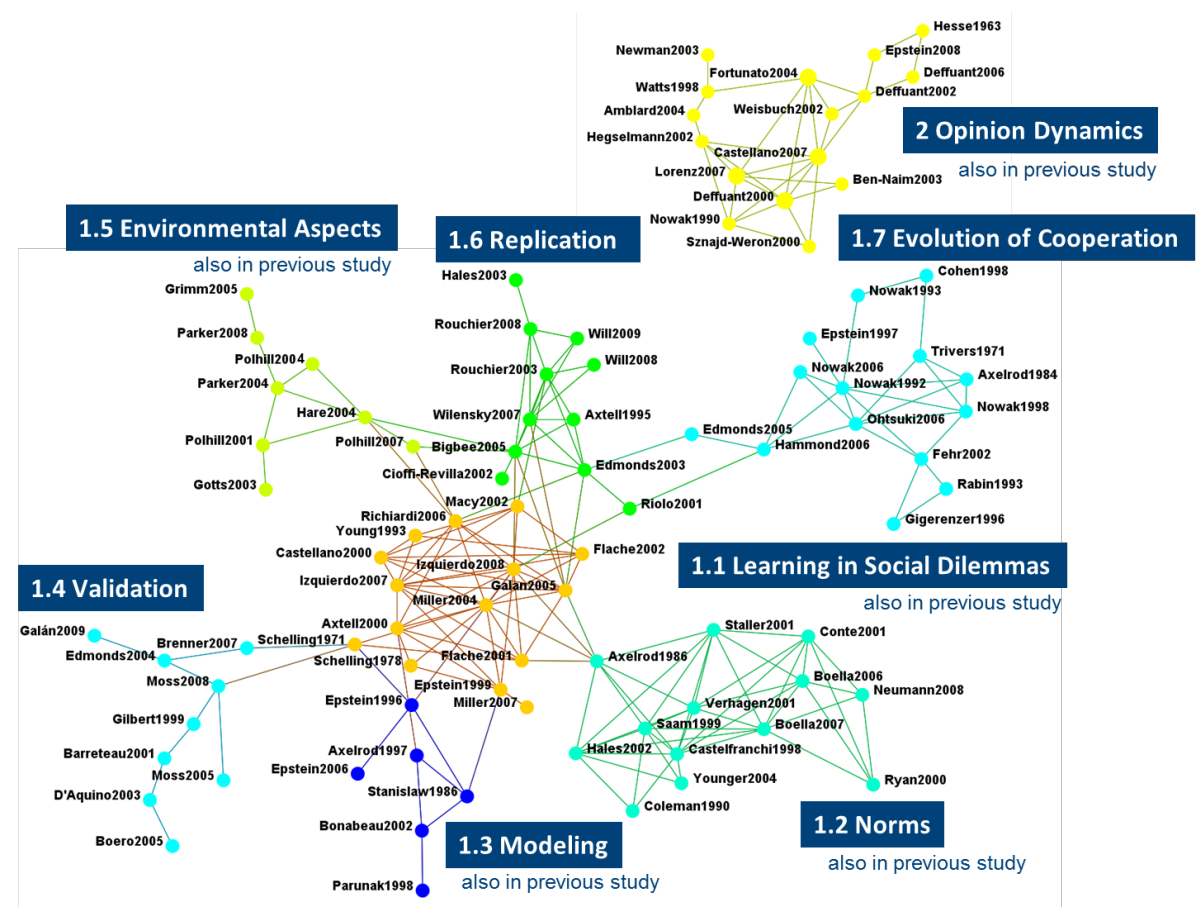

Figure 5: JASSS co-citation network from 2008 to 07/2011 with CoCit scores $\geq 0.25$.

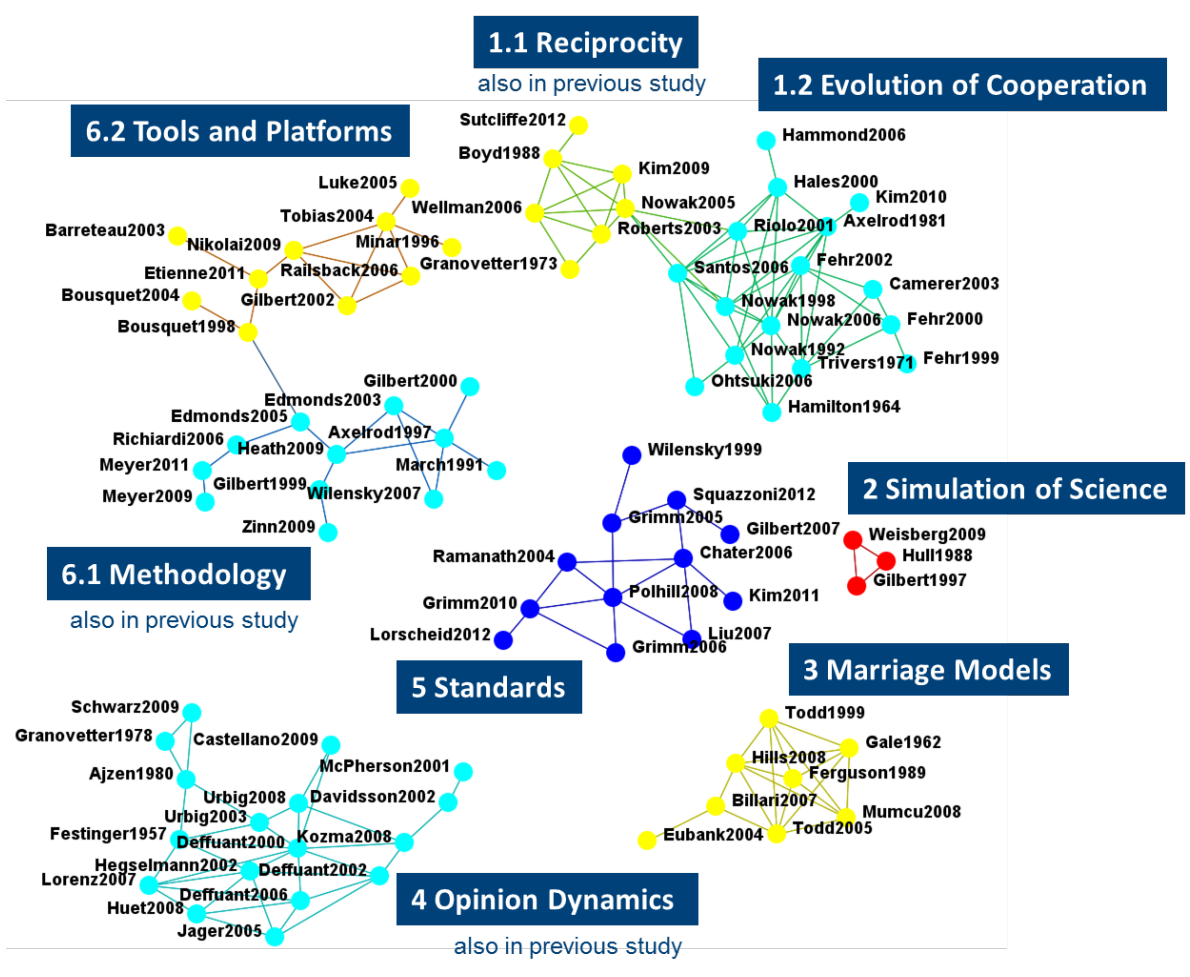

Figure 6: JASSS co-citation network from 08/2011 to 2014 with CoCit scores $\geq 0.25$.

the most recent network are more separated.

5.6 First, we identify some recurrent non-methodological topics in the network. Cluster (1) consists of two contentrelated groups about the research topics (1.1) Reciprocity and (1.2) Evolution of Cooperation. The central publications in this cluster are "Five Rules for the Evolution of Cooperation" (Nowak 2006) and "The Evolution of Cooperation" (Axelrod \& Hamilton 1981), both of which have nine links to other publications in the cluster. The topic Evolution of Cooperation was already identified in the network from 2008-07/2011. In addition, we again found a group related to (4) Opinion Dynamics in the recent network. 


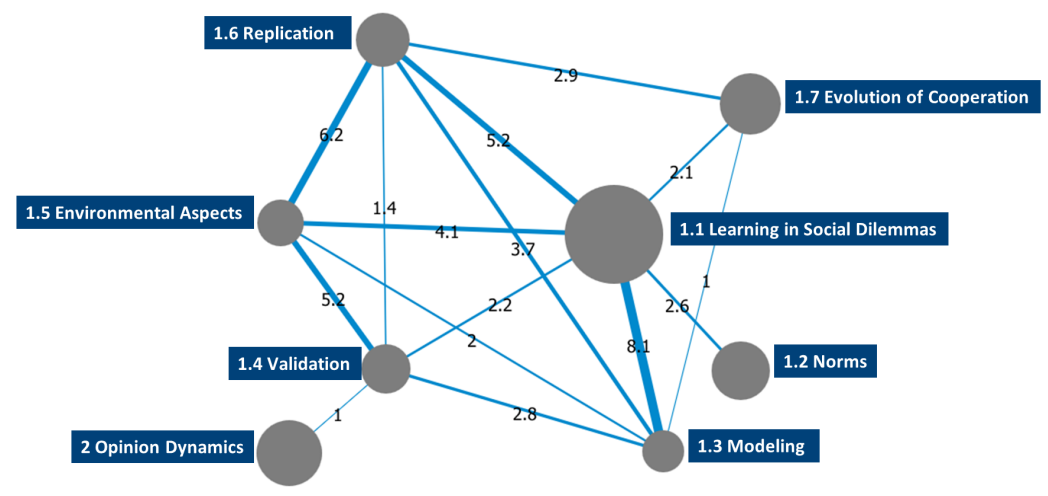

Figure 7: Link strength between the identified groups from 2008 to 07/2011 with GroupCoCit scores $\geq 1.0$.

5.7 Further, new non-methodological topics emerged in the most recent period. The group (3) Marriage Models shows a fully connected network pattern with a density of 0.64 , indicating a strong integration of publications. In addition, the new group (2) Simulation of Science fulfills the minimum criteria of three linked nodes to be depicted in the network.

5.8 Given the co-citation results, social simulation scientists still vividly discuss methodological topics, as three out of eight identified groups deal with methodological aspects. Methodological topics are represented in the most recent period by the groups (5) Standards, (6.1) Methodology, and (6.2) Tools and Platforms. The scientific discussion about tools and platforms is in line with our result from the citation analysis that NetLogo has become an established tool for social simulation researchers (see Section 3 .

5.9 After the identification of groups and their structure within the networks, we investigate how the identified groups are linked with each other. Due to the chosen CoCit score of 0.25 , not all links between groups are depicted. Thus, a further analysis investigates the aggregated strength of connections between groups. To analyze the strength of the connection between group $X$ and $Y$ with $n$ possible links, we calculated the GroupCoCit score as follows (Meyer et al. 2008):

$$
\text { GroupCoCit }_{X Y}=\frac{\sum_{1}^{n} \text { CoCitScore }}{\text { number of nodes }} \text { number of nodes }_{Y} * 100
$$

5.10 Subsequently, we use the same technique as before to visualize the resulting networks. The result for the period from 2008 to $07 / 2011$ is shown in Figure 7 . The average GroupCoCit score is 1.98 and the median is 0.99 . Again, we depict only the value of the strongest GroupCoCit scores between the groups with a threshold of 1.0 (all scores are listed in Appendix B.

5.11 In line with the strongly interconnected co-citation network, we find strong relations among the methodological groups. The weakest link between the methodological groups (1.4) Validation and (1.6) Replication has a GroupCoCit score of 1.4. The other links have relatively high scores, such as a score of 2.8 between (1.4) Validation and (1.3) Modeling and a score of 3.7 between (1.3) Modeling and (1.6) Replication.

5.12 The group (1.1) Learning in Social Dilemmas is centrally located in the network and has six distinct connections to others. Looking more closely at this group, we can identify many publications around general topics such as reinforcement learning (Izquierdo et al.|2008), agent-based models (Epstein 1999), and the prominent publication Why agents?" by Axtell|(2000). Thus, many articles in this group address general issues of agent-based modeling, which is relevant for many research perspectives in social simulation. The centrally located group (1.1) Learning in Social Dilemmas shows no link to the group (2) Opinion Dynamics. This supports our observation that (2) Opinion Dynamics is a rather separated group, while the others are connected.

5.13 The network and GroupCoCit scores for the period from 08/2011 to 2014 are depicted in Figure 8 For the most recent period, we identify considerably low values of the GroupCoCit scores with a mean of 0.52 and a median of 0.26 . This supports our observation concerning the process of differentiation in the most recent period.

5.14 First, we see a triangle among (5) Standards, (6.1) Methodology, and (6.2) Tools and Platforms. As in the previous period, we find strong connections among the methodological topics. The group (6.2) Tools and Platforms is linked with a score of 2.1 to (6.1) Methodology. Similarly strong is the connection between (6.1) Methodology and (5) Standards. A weaker connection exists between (5) Standards and (6.2) Tools and Platforms. 


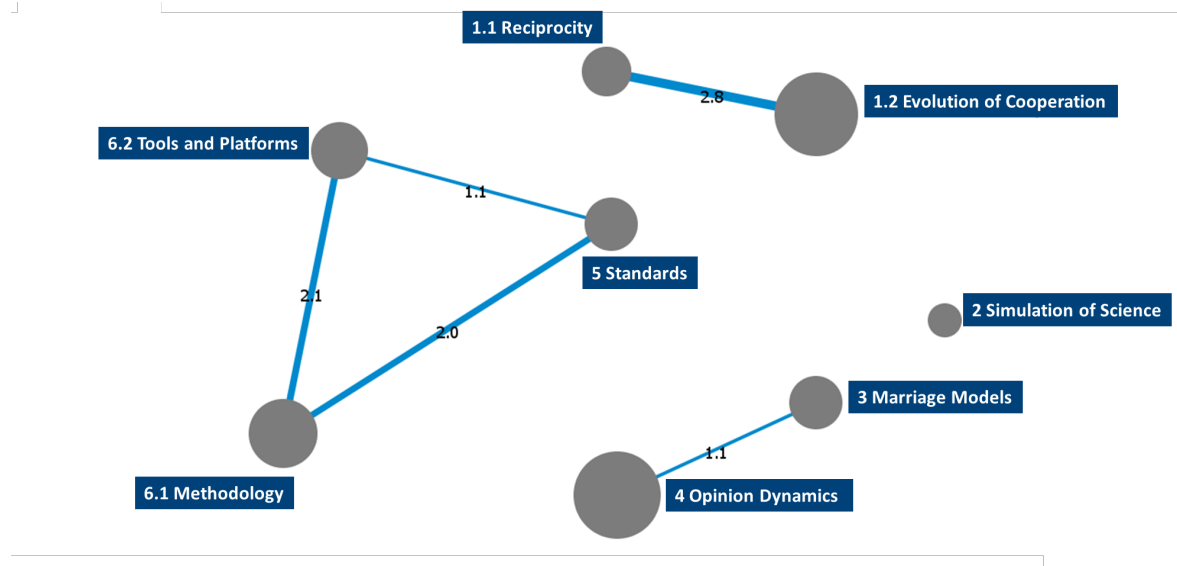

Figure 8: Link strength between the identified groups from 08/2011 to 2014 with GroupCoCit scores $\geq 1.0$.

5.15 The social science-related group (2) Simulation of Science has no links to the methodological groups. In this group, we identify epistemological articles about the structure and process of academic sciences, which can be considered to be an independent branch in social simulation science. The highest link score of 2.8 has the connection between the topics (1.1) Reciprocity and (1.2) Evolution of Cooperation, which indicates a differentiation process of the topics (1.2) Evolution of Cooperation and (1.1) Reciprocity into two distinct groups.

5.16 The two groups (3) Marriage Models and (4) Opinion Dynamics form separate groups that are only connected to each other with a link score of 1.1. (4) Opinion Dynamics was already observed as a rather separated group in the former period. The connection to (3) Marriage Models is mainly driven by the publication "Birds of a feather: Homophily in social networks" (McPherson et al.|2001) about the homophily concept. This publication is located in the group (4) Opinion Dynamics, but is also co-cited with all eight publications in the marriage group ${ }^{15}$. This connection between (4) Opinion Dynamics and (3) Marriage Models exemplifies the interdisciplinary use of common methods and concepts in the community, beyond the variety of topics. Thus, social simulation has interdisciplinary characteristics, represented here, for example, by the links between the groups, as well as multidisciplinary characteristics, as shown by distinguishable groups in the co-citation networks.

\section{Longitudinal Analysis of Social Simulation}

6.1 The co-citation analysis allows us to identify developments in recent years as well as in comparison with the earlier years investigated in Meyer et al. (2009). Given our results of the two analyzed periods, a certain level of stability is observable, while at the same time some issues have been dropped and new topics have emerged. Methodological topics are strongly represented in both periods, as are the topics Opinion Dynamics and Evolution of Cooperation. On the other hand, some topics only emerged recently such as Marriage Models, Simulation of Science, and Tools and Platforms. In contrast, other topics disappeared such as environmental aspects and learning. This illustrates the dynamic processes in JASSS.

6.2 Overall, the results of this final analysis suggest that the research topics in the most recent period are more distinguishable and less strongly cross-linked. Methodological issues form their own clusters and groups, while several social science-related issues have evolved over time. The coexistence of methodological and social science-related subjects can be seen as a major pattern emerging from our co-citation analysis.

6.3 To foster the interpretation of the longitudinal development, we provide a rank flow chart. Figure 9 highlights the issues discussed in JASSS, as identified by co-citation analyses, along the 17-year editorship of Nigel Gilbert. The topics are ranked according to the number of publications per topic-related group ${ }^{16}$. For an overview of network metrics within the co-citation networks for all periods, see Appendix C.

6.4 Clearly visible is the dominance of Opinion Dynamics as the biggest cluster in the recent three periods. This shows that Opinion Dynamics has developed into a long-term topic for social simulation researchers. Similar is the development of Evolution of Cooperation, which emerged in the last two periods. Alongside this, the development of the topic Reciprocity is closely connected to Evolution of Cooperation.

6.5 Overall, three topics were prominent in three periods: Methodology, Opinion Dynamics, and Norms. These topics may constitute social simulation as a discipline. However, the fact that several non-methodological topics 


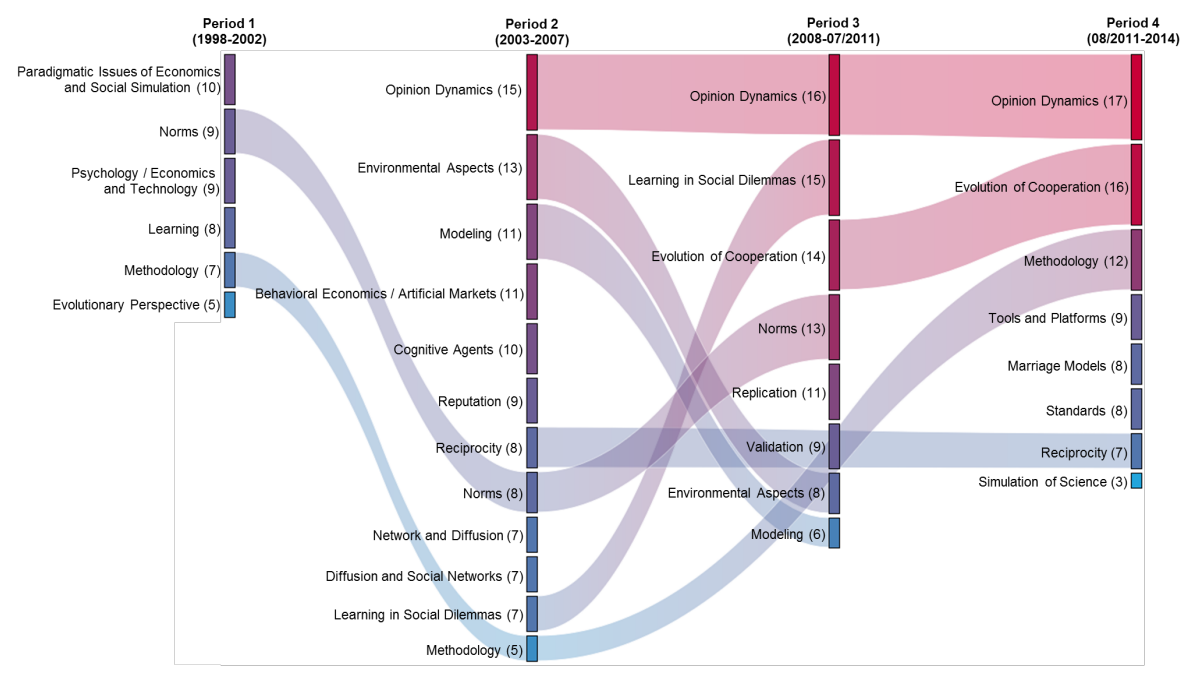

Figure 9: Rank changes of social simulation research topics discussed in JASSS from 1998 to 2014.

dropped, changed, and emerged over time indicates the multidisciplinary character of JASSS and the domain of social simulation. Noticeably, no topic is represented in all four periods.

6.6 Methodological issues have occurred in each analyzed period since the foundation of JASSS. Within this, processes of differentiation and consolidation are observable. In the very first years from 1998 to 2002, just a single group about the methodology of social simulation was identified. From 2003 to 2007, two distinct methodological topics emerged: Modeling and Methodology. In the third period from 2008 to 07/2011, we identified the topics replication, validation, and modeling. Recently, in the fourth period from 08/2011 to 2014, three topics cover methodological aspects, which are Methodology, Standards, and Tools and Platforms.

6.7 One can speculate whether this reflects the development of the research method simulation in the social sciences. First, general methodological aspects were discussed, informed initially by books such as Gilbert and Troitzsch's text 2005. Next, issues such as the ghost in the model (Polhill et al.2004), simulation model alignment (Epstein \& Axtell 1996), and the value of replication (Edmonds \& Hales 2003) became relevant for the first applications, discussed in the groups Modeling and Methodology in the second period. In the next period, Replication and Validation became such prominent topics that they emerged as groups of their own in the co-citation network. In recent years, the maturity of the method can be recognized by the development of tools, platforms, and standards as prominent topics and thus individual groups.

6.8 The topic Environmental Aspects was a big group in the co-citation network of the second period, yet it became a smaller group in the third period and disappeared in the last. There are many simulation studies of environmental aspects such as socio-ecological systems. Possibly, the discussions of environmental aspects shifted to other journals outside JASSS. Here, we identified more referenced journals in environment and ecology in recent years.

6.9 The theme Network and Diffusion only emerged in the second period but disappeared thereafter. Still, the citation analysis shows that the publication "Collective dynamics of 'small-world' networks" by Watts \& Strogatz (1998) remains one of the most cited publications in JASSS. Thus, the topic Network and Diffusion seems to merge with other fields of social simulation.

\section{Conclusion}

7.1 This paper investigates the recent development of social simulation as reflected in articles published in JASSS from 2008 to 2014 by means of bibliometric methods. Therby, it offers several theoretical and practical contributions. First, it provides an empirical basis from which to discuss the intellectual structure of JASSS and the related community. The results from the citation and co-citation analysis confirm the continuing multidisciplinary nature of JASSS, which is in line with its self-characterization. Further, the interdisciplinary exchange of knowledge extends beyond the boundaries of single disciplines and can be considered to be a distinctive characteristic of both the journal and the discipline. Furthermore, the citation analysis identifies NetLogo Wilensky 1999 as the most cited source, which indicates that it has become an important modeling environment in 
the field of social simulation. The most cited sources as well as the co-citation networks indicate that general methodological issues are vividly discussed by the researchers publishing in JASSS. This result underpins the perceived role of JASSS as an interface for many researchers in the social sciences, who are linked with each other due to their common research interests in method simulation.

7.2 Second, in combination with the previous study, changes and continuities can be identified over the longer time span of 17 years. Looking at the most cited sources, several publications persist with high citation values, particularly Axelrod (2006); Epstein \& Axtell 1996); Gilbert \& Troitzsch 2005). This result highlights some of the well-established publications in the social simulation community. The trend to acknowledge more journal articles continues, as already identified in the previous study (Meyer et al. 2009). At the same time, some frequently cited book publications in the first years of JASSS lost their relevance. The citation results show that certain standards such as the ODD protocol Grimm et al. 2006, 2010) and tools such as NetLogo (Wilensky 1999) are now more frequently cited and thus are becoming increasingly established among researchers in the field. This observation indicates that the field might be evolving into a discipline with shared tools and standards. Along this line, the co-citation analysis depicts two long-term research topics in the field, which are Opinion Dynamics and Evolution. We conclude that these research fields are well-established in JASSS. On the other hand, new topics such as marriage formation and the simulation of science indicate a certain dynamic and openness concerning the main topics discussed in JASSS.

7.3 Third, this study may provide an orientation for newcomers to the field. The list of most cited publications gives an overview of the basic literature and illuminates the standards and tools currently in use in the field, such as the ODD protocol and NetLogo. The co-citation networks display the current (and past) topics and their main publications. In combination with the publications citing them, these offer good starting points for individuals seeking to become familiar with the specific topics or the field in general.

7.4 As with any study, this paper has limitations. First, we focused on a single journal, while also drawing some more general conclusions regarding social simulation. For a more comprehensive overview of the development of social simulation, more journals and proceedings should be included in the analysis. However, since JASSS is the main journal in the field, it is thus a good indicator for analyzing the general development. Moreover, citation studies suffer from a certain time lag, as it takes some time for publications to appear and to be referenced by other authors. Further, we subdivided the seven-year time span into two equal 3.5 year periods to have a comparable picture about overall development with the previous study. Another subdivision may lead to slightly different results. The analysis also needs to be restricted to the most cited publications for reasons of complexity reduction. Still, we conducted robustness tests with varying CoCit scores, which overall showed similar qualitative results.

7.5 Future research could, besides addressing these limitations, use different bibliometric methods such as author co-citation analysis or bibliographic coupling. Further, the set of investigated articles could be extended by using a key word search and related methods to identify relevant papers. Finally, additional insights could be gained from repeating this study in some years to map the next steps in the development of JASSS and social simulation. Still, we hope that this study currently fosters the understanding and acknowledgement of the development of the intellectual structure of JASSS and its related community of social simulation.

\section{Acknowledgements}

We would like to thank the anonymous reviewers for their valuable comments and suggestions that helped us to enhance the quality of the article. We would also like to thank the participants of the Social Simulation Conference 2015 (Groningen, NL) for the discussion and supportive feedback to this study. This publication was supported by the German Research Foundation (DFG) and the Hamburg University of Technology (TUHH) in the funding program "Open Access Publishing". 


\begin{tabular}{|c|c|c|}
\hline Short citation & Publication & Number of links \\
\hline \multicolumn{3}{|c|}{ 1.1 Learning in Social Dilemmas (15 nodes, 84 links, density 0.400) } \\
\hline Izquierdo2008 & $\begin{array}{l}\text { IZQUIERDO, S. S., Izquierdo, L. R. \& Gotts, N. M. (2008). } \\
\text { Reinforcement learning dynamics in social dilemmas. } \\
\text { Journal of Artificial Societies and Social Simulation, 11(2), } \\
\text { 1. }\end{array}$ & 10 \\
\hline Izquierdo2007 & $\begin{array}{l}\text { IZQUIERDO, L. R., Izquierdo, S. S., Gotts, N. M. \& Polhill, } \\
\text { J. G. (2007). Transient and asymptotic dynamics of rein- } \\
\text { forcement learning in games. Games and Economic Be- } \\
\text { havior, 61(2), 259-276. }\end{array}$ & 9 \\
\hline Miller2004 & $\begin{array}{l}\text { MILLER, J. H. \& Page, S. E. (2004). The standing ovation } \\
\text { problem. Complexity, 9(5), 8-16 }\end{array}$ & 9 \\
\hline Galan2005 & $\begin{array}{l}\text { GALAN, J. M. \& Izquierdo, L. R. (2005). Appearances can } \\
\text { be deceiving: Lessons learned re-implementing Axel- } \\
\text { rod's 'Evolutionary Approach to Norms.' Journal of Ar- } \\
\text { tificial Societies and Social Simulation, 8(3), } 2 \text {. }\end{array}$ & 7 \\
\hline Epstein1999 & $\begin{array}{l}\text { EPSTEIN, J. M. (1999). Agent-based computational } \\
\text { models and generative social science. Complexity, } 4(5) \text {, } \\
41-60 .\end{array}$ & 6 \\
\hline Flache2002 & $\begin{array}{l}\text { FLACHE, A. \& Macy, M. W. (2002). Stochastic collusion } \\
\text { and the power law of learning. Journal of Conflict Reso- } \\
\text { lution, 46(5), 629-653. }\end{array}$ & 6 \\
\hline Axtell2000 & $\begin{array}{l}\text { AXTELL, R. L. (2000). Why agents? On the varied mo- } \\
\text { tivations for agent computing in the social sciences. In } \\
\text { Macal, C. M. \& Sallach, D. (Eds.) Proceedings of the } \\
\text { Workshop on Agent Simulation: Applications, Models, } \\
\text { and Tools, 3-24. Argonne, IL: Argonne National Labora- } \\
\text { tory. }\end{array}$ & 6 \\
\hline Castellano2000 & $\begin{array}{l}\text { CASTELLANO, C., Marsili, M. \& Vespignani, A. (2000). } \\
\text { Nonequilibrium phase transition in a model for social } \\
\text { influence. Physical Review Letters, 85(16), 3536-3539. }\end{array}$ & 6 \\
\hline Flache2001 & $\begin{array}{l}\text { FLACHE, A. \& Hegselmann, R. (2001). Do irregular grids } \\
\text { make a difference? Relaxing the spatial regularity as- } \\
\text { sumption in cellular models of social dynamics. Journal } \\
\text { of Artificial Societies and Social Simulation, } 4(4), 6 \text {. }\end{array}$ & 5 \\
\hline Macy2002 & $\begin{array}{l}\text { MACY, M. W. \& Flache, A. (2002). Learning dynamics in } \\
\text { social dilemmas. Proceedings of the National Academy } \\
\text { of Sciences of the United States of America, 99(3), 7229- } \\
7236 \text {. }\end{array}$ & 5 \\
\hline Richiardi2006 & $\begin{array}{l}\text { RICHIARDI, M. R., Leombruni, R., Saam, N. \& Sonnessa, } \\
\text { M. (2006). A common protocol for agent-based social } \\
\text { simulation. Journal of Artificial Societies and Social Sim- } \\
\text { ulation, } 9(1), 15 \text {. }\end{array}$ & 5 \\
\hline Young1993 & $\begin{array}{l}\text { YOUNG, H. P. (1993). The evolution of conventions. } \\
\text { Econometrica, } 61(1), 57-84 \text {. }\end{array}$ & 4 \\
\hline Schelling1978 & $\begin{array}{l}\text { SCHELLING, T. C. (1978). Micromotives and Macrobehav- } \\
\text { ior. New York, NY: Norton. }\end{array}$ & 3 \\
\hline Schelling1971 & $\begin{array}{l}\text { SCHELLING, T.C. (1971). Dynamic models of segregation. } \\
\text { Journal of Mathematical Sociology, (1), 143-186. }\end{array}$ & 2 \\
\hline Miller2007 & $\begin{array}{l}\text { MILLER, J. H. \& Page, S. E. (2007). Complex Adaptive Sys- } \\
\text { tems: An Introduction to Computational Models of Social } \\
\text { Life. Princeton, NJ: Princeton University Press. }\end{array}$ & 1 \\
\hline
\end{tabular}




\begin{tabular}{|c|c|c|}
\hline Short citation & Publication & Number of links \\
\hline \multicolumn{3}{|c|}{ 1.2 Norms (13 nodes, 80 links, density 0.513 ) } \\
\hline Castelfranchi1998 & $\begin{array}{l}\text { CASTELFRANCHI, C., Conte, R. \& Paolucci, M. (1998). } \\
\text { Normative reputation and the costs of compliance. } \\
\text { Journal of Artificial Societies and Social Simulation, 1(3), } \\
\text { 3. }\end{array}$ & 10 \\
\hline Boella2007 & $\begin{array}{l}\text { BOELLA, G., van der Torre, L. \& Verhagen, H. (2007). In- } \\
\text { troduction to normative multiagent systems. Dagstuhl } \\
\text { Seminar Proceedings, } 07122 \text {. }\end{array}$ & 9 \\
\hline Saam1999 & $\begin{array}{l}\text { SAAM, N. \& Harrer, A. (1999). Simulating norms, social } \\
\text { inequality, and functional change in artificial societies. } \\
\text { Journal of Artificial Societies and Social Simulation, 2(1), } \\
2 .\end{array}$ & 8 \\
\hline Staller2001 & $\begin{array}{l}\text { STALLER, A. \& Petta, P. (2001). Introducing emotions } \\
\text { into the computational study of social norms: A first } \\
\text { evaluation. Journal of Artificial Societies and Social Sim- } \\
\text { ulation, } 4(1), 2 \text {. }\end{array}$ & 8 \\
\hline Boella2006 & $\begin{array}{l}\text { BOELLA, G. \& van der Torre, L. (2006). An architecture } \\
\text { of a normative system: Counts-as conditionals, obliga- } \\
\text { tions and permissions. In Proceedings of the Fifth In- } \\
\text { ternational Joint Conference on Autonomous Agents and } \\
\text { Multiagent Systems (pp. 229-231). ACM. }\end{array}$ & 7 \\
\hline Verhagen 2001 & $\begin{array}{l}\text { VERHAGEN, H. (2001). Simulation of the learning of } \\
\text { norms. Social Science Computer Review, 19(3), 296-306. }\end{array}$ & 7 \\
\hline Hales2002 & $\begin{array}{l}\text { HALES, D. (2002). Group reputation supports benefi- } \\
\text { cent norms. Journal of Artificial Societies and Social Sim- } \\
\text { ulation, 5(4), } 4 \text {. }\end{array}$ & 7 \\
\hline Axelrod1986 & $\begin{array}{l}\text { AXELROD, R. M. (1986). An evolutionary approach to } \\
\text { norms. American Political Science Review, } 80(4) \text {, 1095- } \\
1111 .\end{array}$ & 6 \\
\hline Neumann2008 & $\begin{array}{l}\text { NEUMANN, M. (2008b). Homo socionicus: A case study } \\
\text { of simulation models of norms. Journal of Artificial So- } \\
\text { cieties and Social Simulation, 11(4), } 6 \text {. }\end{array}$ & 4 \\
\hline Ryan2000 & $\begin{array}{l}\text { RYAN, R. M. \& Deci, E. L. (2000). Self-determination the- } \\
\text { ory and the facilitation of intrinsic motivation: Social } \\
\text { developments and well-being. American Psychologist, } \\
\text { (55), 68-78. }\end{array}$ & 4 \\
\hline Conte2001 & $\begin{array}{l}\text { CONTE, R. \& Dignum, F. (2001). From social monitor- } \\
\text { ing to normative influence. Journal of Artificial Societies } \\
\text { and Social Simulation, } 4(2), 7 \text {. }\end{array}$ & 4 \\
\hline Coleman1990 & $\begin{array}{l}\text { COLEMAN, J. S. (1990). Foundations of Social Theory. } \\
\text { Cambridge: Cambridge University Press. }\end{array}$ & 3 \\
\hline Younger2004 & $\begin{array}{l}\text { YOUNGER, S. (2004). Reciprocity, normative reputation, } \\
\text { and the development of mutual obligation in gift-giving } \\
\text { societies. Journal of Artificial Societies and Social Simu- } \\
\text { lation, } 7(1), 5 \text {. }\end{array}$ & 3 \\
\hline \multicolumn{3}{|c|}{1.3 Modeling (6 nodes, 12 links, density 0.4 ) } \\
\hline Stanislaw1986 & $\begin{array}{l}\text { STANISLAW, H. (1986). Tests of computer simulation va- } \\
\text { lidity. What do they measure? Simulation and Games, } \\
\text { (17), 173-191. }\end{array}$ & 3 \\
\hline Bonabeau2002 & $\begin{array}{l}\text { BONABEAU, E. (2002). Agent-based modeling: Meth- } \\
\text { ods and techniques for simulating human systems. Pro- } \\
\text { ceedings of the National Academy of Sciences of the } \\
\text { United States of America, (99), 7280-7287. }\end{array}$ & 3 \\
\hline
\end{tabular}




\begin{tabular}{ll}
\hline Short citation & Publication \\
\hline Epstein1996 & EPSTEIN, J. M. \& Axtell, R. (1996). Growing Artificial Soci- \\
& eties: Social Science from the Bottom up. Complex Adap- \\
& tive Systems. Washington, D.C., Cambridge, MA, Lon- \\
don: Brookings Institution Press: MIT Press. & AXELRO, R. (1997). Advancing the art of simulation \\
in the social sciences. In Conte, R., Hegselmann, R. \& & Terna, P. (eds.) Simulating Social Phenomena, Lecture \\
& Notes in Economics and Mathematical Systems, Berlin: \\
& SpringerVerlag. \\
& EPSTEIN, J. M. (2006). Generative Social Science: Studies \\
& in Agent-Based Computational Modeling. Princeton, NJ: \\
Princeton University Press. & \\
PARUNAK, H. V. D., Savit, R. \& Riolo, R. L. (1998). Agent- & based modeling vs. equation-based modeling: A case \\
Parunak1998 & study and users' guide. In: Workshop on Multi-Agent Sys- \\
& tems and Agent-Based Simulation, Springer, 10-25.
\end{tabular}

\subsection{Validation (9 nodes, 17 links, density 0.236 )}

Moss 2008

Edmonds2004

Gilbert1999

Barreteau2001

Brenner2007

D’Aquino2003

Moss2005

Galán2009

Boero2005
MOSS, S. (2008). Alternative approaches to the empirical validation of agent-based models. Journal of Artificial Societies and Social Simulation, 11(1), 5

EDMONDS, B. \& Moss, S. J. (2004). From KISS to KIDS - An 'antisimplistic' modelling approach. In: P. Davidsson et al. (eds.). Multi agent-based simulation. Lecture Notes in Artificial Intelligence, (3415), 130-144

GILBERT, N. \& Troitzsch, K. G. (1999). Simulation for the Social Scientist. Buckingham, UK: Open University Press

BARRETEAU, O., Bousquet, F. \& Attonaty, J. M. (2001). Role-playing games for opening the black box of multiagent systems: Method and lessons of its application to Senegal River Valley irrigated systems. Journal of Artificial Societies and Social Simulation, 4(2), 5

BRENNER, T. \& Werker, C. (2007). A taxonomy of inference in simulation models. Computational Economics, (30), 227-244

D’AQUINO, P., Le Page, C., Bousquet, F. \& Bah, A. (2003). Using self-designed role-playing games and a multiagent systems to empower a local decision-making process for land use management: The SelfCormas experiment in Senegal. Journal of Artificial Societies and Social Simulation, 6(3), 5

MOSS, S. \& Edmonds, B. (2005). Sociology and simulation: Statistical and qualitative cross-validation. American Journal of Sociology, 110(4), 1095-1131

GALÁN, J. M., Izquierdo, L. R., Izquierdo, S. S., Santos, J. I., del Olmo, R., López-Paredes, A. \& Edmonds, B. (2009). Errors and artefacts in agent-based modelling. Journal of Artificial Societies and Social Simulation, 12(1), 1 BOERO, R. \& Squazzoni, F. (2005). Does empirical embeddedness matter? Methodological issues on agentbased models for analytical social science. Journal of Artificial Societies and Social Simulation, 8(4), 6 


\begin{tabular}{|c|c|c|}
\hline Short citation & Publication & Number of links \\
\hline \multicolumn{3}{|c|}{1.5 Environmental Aspects (8 nodes, 19 links, density 0.339) } \\
\hline Hare2004 & $\begin{array}{l}\text { HARE, M. \& Deadman, P. J. (2004). Further towards a tax- } \\
\text { onomy of agent-based simulation models in environ- } \\
\text { mental management. Mathematics and Computers in } \\
\text { Simulation, } 64(1), 25-40\end{array}$ & 5 \\
\hline Parker2004 & $\begin{array}{l}\text { PARKER, D. C. \& Meretsky, V. (2004). Measuring pattern } \\
\text { outcomes in an agent-based model of edge-effect exter- } \\
\text { nalities using spatial metrics. Agriculture, Ecosystems } \\
\text { and Environment, (101), 233-250 }\end{array}$ & 4 \\
\hline Polhill2001 & $\begin{array}{l}\text { POLHILL, J. G., Gotts, N. M. \& Law, A. N. R. (2001). Imita- } \\
\text { tive versus nonimitative strategies in a land use simula- } \\
\text { tion. Cybernetics and Systems. } 32(1-2), 285-307\end{array}$ & 3 \\
\hline Parker2008 & $\begin{array}{l}\text { PARKER, D. C., Brown, D. G., Polhill, J. G., Deadman, P. } \\
\text { J. \& Manson, S. M. (2008). Illustrating a new 'conceptual } \\
\text { design pattern' for agent-based models and land use via } \\
\text { five case studies: The MR POTATOHEAD framework. In } \\
\text { López-Paredes, A. \& Hernandez-Iglesias, C. (Eds.) Agent- } \\
\text { Based Modelling in Natural Resource Management. Val- } \\
\text { ladolid, Spain: Universidad de Valladolid, 23-51 }\end{array}$ & 2 \\
\hline Polhill2004 & $\begin{array}{l}\text { POLHILL, J. G., Izquierdo, L. R. \& Gotts, N. M. (2004). The } \\
\text { ghost in the model (and other effects of floating point } \\
\text { arithmetic). Journal of Artificial Societies and Social } \\
\text { Simulation, 8(1),5 }\end{array}$ & 2 \\
\hline Polhill2007 & $\begin{array}{l}\text { POLHILL, J. G., Pignotti, E., Gotts, N. M., Edwards, P. } \\
\text { \& Preece, A. (2007). A semantic grid service for ex- } \\
\text { perimentation with an agent-based model of land-use } \\
\text { change. Journal of Artificial Societies and Social Simu- } \\
\text { lation, } 10(2), 2\end{array}$ & 1 \\
\hline Gotts2003 & $\begin{array}{l}\text { GOTTS, N. M., Polhill, J. G. \& Law, A. N. R. (2003). Aspi- } \\
\text { ration levels in a land use simulation. Cybernetics and } \\
\text { Systems, (34), 663-683 }\end{array}$ & 1 \\
\hline Grimm2005 & $\begin{array}{l}\text { GRIMM, V., Revilla, E., Berger, U.,..., DeAngelis, D. L. } \\
\text { (2005). Pattern-oriented modeling of agent-based com- } \\
\text { plex systems: Lessons from ecology. Science, (310), } \\
987-991\end{array}$ & 1 \\
\hline \multicolumn{3}{|c|}{ 1.6 Replication (11 nodes, 44 links, density 0.364) } \\
\hline Rouchier2003 & $\begin{array}{l}\text { ROUCHIER, J. (2003). Re-implementation of a multi- } \\
\text { agent model aimed at sustaining experimental eco- } \\
\text { nomic research: The case of simulations with emerg- } \\
\text { ing speculation. Journal of Artificial Societies and So- } \\
\text { cial Simulation, } 6(4), 7\end{array}$ & 8 \\
\hline Edmonds2003 & $\begin{array}{l}\text { EDMONDS, B. \& Hales, D. (2003). Replication, replica- } \\
\text { tion and replication: Some hard lessons from model } \\
\text { alignment. Journal of Artificial Societies and Social } \\
\text { Simulation, 6(4), } 11\end{array}$ & 7 \\
\hline Bigbee2005 & $\begin{array}{l}\text { BIGBEE, A., Cioffi-Revilla, C. \& Luke, S. (2005). Repli- } \\
\text { cation of sugarscape using MASON. In Troitzsch, K. G. } \\
\text { (Ed.) Representing social reality: Pre-proceedings of } \\
\text { the third conference of the European Social Simulation } \\
\text { Association, Koblenz, September 5-9, 2005. Koblenz: } \\
\text { Verlag Dietmar Fölbach, 6-15 }\end{array}$ & 6 \\
\hline
\end{tabular}




\begin{tabular}{|c|c|c|}
\hline Short citation & Publication & Number of links \\
\hline Parker2008 & $\begin{array}{l}\text { PARKER, D. C., Brown, D. G., Polhill, J. G., Deadman, P. } \\
\text { J. \& Manson, S. M. (2008). Illustrating a new 'conceptual } \\
\text { design pattern' for agent-based models and land use via } \\
\text { five case studies: The MR POTATOHEAD framework. In } \\
\text { López-Paredes, A. \& Hernandez-Iglesias, C. (Eds.) Agent- } \\
\text { Based Modelling in Natural Resource Management. Val- } \\
\text { ladolid, Spain: Universidad de Valladolid, 23-51 }\end{array}$ & 2 \\
\hline Wilensky2007 & $\begin{array}{l}\text { WILENSKY, U. \& RAND, W. (2007). Making models match: } \\
\text { Replicating an agent-based model. Journal of Artificial } \\
\text { Societies and Social Simulation, 10(4), } 2\end{array}$ & 6 \\
\hline Rouchier2008 & $\begin{array}{l}\text { ROUCHIER, J., Cioffi-Revilla, C., Polhill, J. G. \& } \\
\text { Takadama, K. (2008). Progress in model-to-model } \\
\text { analysis. Journal of Artificial Societies and Social } \\
\text { Simulation, 11(2), } 8\end{array}$ & 5 \\
\hline Axtell1995 & $\begin{array}{l}\text { AXTELL, R., Axelrod, R., Epstein, J. \& Cohen, M. D. (1995). } \\
\text { Aligning simulation models: A case study and results. } \\
\text { Computational and Mathematical Organization Theory, } \\
\text { 1(1), 123-141 }\end{array}$ & 4 \\
\hline Will2009 & $\begin{array}{l}\text { WILL, O. (2009). Resolving a replication that failed: } \\
\text { News on the Macy \& Sato model. Journal of Artificial } \\
\text { Societies and Social Simulation, 12(4)11 }\end{array}$ & 3 \\
\hline Will2008 & $\begin{array}{l}\text { WILL, O. \& Hegselmann, R. (2008). A replication that } \\
\text { failed: On the computational model in 'Michael W. Macy } \\
\text { and Yoshimichi Sato: Trust, cooperation and market for- } \\
\text { mation in the U.S. and Japan. Proceedings of the Na- } \\
\text { tional Academy of Sciences, May 2002.' Journal of Arti- } \\
\text { ficial Societies and Social Simulation, 11(3), } 3\end{array}$ & 2 \\
\hline Cioffi-Revilla2002 & $\begin{array}{l}\text { CIOFFI-REVILLA, C. (2002). Invariance and universality } \\
\text { in social agent-based simulations. Proceedings of the } \\
\text { National Academy of Science of the USA, 99(10)3, 7314- } \\
7316\end{array}$ & 1 \\
\hline Riolo2001 & $\begin{array}{l}\text { RIOLO, R. L., Cohen, M. D. \& Axelrod, R. M. (2001). Evo- } \\
\text { lution of cooperation without reciprocity. Nature, 411, } \\
441-443\end{array}$ & 1 \\
\hline Hales2003 & $\begin{array}{l}\text { HALES, D., Rouchier, J. \& Edmonds, B. (2003). Model-to- } \\
\text { model analysis. Journal of Artificial Societies and Social } \\
\text { Simulation, 6(4), } 5\end{array}$ & 1 \\
\hline \multicolumn{3}{|c|}{ 1.7 Evolution of Cooperation (14 nodes, 49 links, density 0.269 ) } \\
\hline Nowak1992 & $\begin{array}{l}\text { NOWAK, M. A. \& May, R. M. (1992). Evolutionary games } \\
\text { and spatial chaos. Nature, 359, 826-829 }\end{array}$ & 8 \\
\hline Ohtsuki2006 & $\begin{array}{l}\text { OHTSUKI, H., Hauert, C., Lieberman, E. \& Nowak, M. A. } \\
\text { (2006). A simple rule for the evolution of cooperation } \\
\text { on graphs and social networks. Nature, 441, 502-505 }\end{array}$ & 7 \\
\hline Bigbee2005 & $\begin{array}{l}\text { NOWAK, M. A. \& May, R. M. (1992). Evolutionary games } \\
\text { and spatial chaos. Nature, 359, 826-829 }\end{array}$ & 8 \\
\hline Ohtsuki2006 & $\begin{array}{l}\text { OHTSUKI, H., Hauert, C., Lieberman, E. \& Nowak, M. A. } \\
\text { (2006). A simple rule for the evolution of cooperation } \\
\text { on graphs and social networks. Nature, 441, 502-505 }\end{array}$ & 7 \\
\hline Nowak1998 & $\begin{array}{l}\text { NOWAK, M. A. \& Sigmund, K. (1998). Evolution of indi- } \\
\text { rect reciprocity by image scoring. Nature, 393, 573-577 }\end{array}$ & 5 \\
\hline Axelrod1984 & $\begin{array}{l}\text { AXELROD, R. (1984). The Evolution of Cooperation. New } \\
\text { York, NY: Basic Books }\end{array}$ & 4 \\
\hline Trivers1971 & $\begin{array}{l}\text { TRIVERS, R. L. (1971). The evolution of reciprocal altru- } \\
\text { ism. Quarterly Review of Biology, 46, 35-57 }\end{array}$ & 4 \\
\hline
\end{tabular}




\begin{tabular}{|c|c|c|}
\hline Short citation & Publication & Number of links \\
\hline Fehr2002 & $\begin{array}{l}\text { FEHR, E. \& Gächter, S. (2002). Altruistic punishment in } \\
\text { humans. Nature, } 415,137-140\end{array}$ & 4 \\
\hline Hammond2006 & $\begin{array}{l}\text { HAMMOND, R. A. \& Axelrod, R. M. (2006). Evolution } \\
\text { of contingent altruism when cooperation is expensive. } \\
\text { Theoretical Population Biology, } 69(3), 333-338\end{array}$ & 4 \\
\hline Nowak2006 & $\begin{array}{l}\text { NOWAK, M. A. (2006). Five rules for the evolution of co- } \\
\text { operation. Science, } 314,1560-1563\end{array}$ & 3 \\
\hline Nowak1993 & $\begin{array}{l}\text { NOWAK, M. A. \& Sigmund, K. (1993). A strategy of win- } \\
\text { stay, lose-shift that outperforms tit-for-tat in the Pris- } \\
\text { oner's Dilemma game. Nature, } 364,56-58\end{array}$ & 2 \\
\hline Rabin1993 & $\begin{array}{l}\text { RABIN, M. (1993). Incorporating fairness into game the- } \\
\text { ory and economics. American Economic Review, 83, } \\
1281-1302\end{array}$ & 2 \\
\hline Gigerenzer1996 & $\begin{array}{l}\text { GIGERENZER, G. \& Goldstain, D. G. (1996). Reasoning } \\
\text { the fast and frugal way: Models of bounded rationality. } \\
\text { Psychological Review, 103, 650-669 }\end{array}$ & 2 \\
\hline Cohen1998 & $\begin{array}{l}\text { COHEN, M., Riolo, R. \& Axelrod, R. (1998). The emer- } \\
\text { gence of social organization in the Prisoner's Dilemma: } \\
\text { How context preservation and other factors promote } \\
\text { cooperation. Santa Fe Institute, Working Paper, 99-01- } \\
002\end{array}$ & 2 \\
\hline Edmonds 2005 & $\begin{array}{l}\text { EDMONDS, B. \& Hales, D. (2005). Computational simu- } \\
\text { lation as theoretical experiment. Journal of Mathemat- } \\
\text { ical Sociology, 29(3), 209-232 }\end{array}$ & 1 \\
\hline Epstein1997 & $\begin{array}{l}\text { EPSTEIN, J. M. (1997). Zones of cooperation in demo- } \\
\text { graphic Prisoner's Dilemma. Complexity, 4(2), 36-48 }\end{array}$ & 1 \\
\hline \multicolumn{3}{|c|}{2 Opinion Dynamics (16 nodes, 58 links, density 0.242) } \\
\hline Castellano2007 & $\begin{array}{l}\text { CASTELLANO, C., Fortunato, S. \& Loreto, V. (2007). Sta- } \\
\text { tistical physics of social dynamics. Reviews of Modern } \\
\text { Physics, 81, } 591\end{array}$ & 8 \\
\hline Deffuant2000 & $\begin{array}{l}\text { DEFFUANT, G., Neau, D., Amblard, F. \& Weisbuch G. } \\
\text { (2000). Mixing beliefs among interacting agents. Ad- } \\
\text { vances in Complex Systems, 3, } 87-98\end{array}$ & 7 \\
\hline Fortunato2004 & $\begin{array}{l}\text { FORTUNATO, S. (2004). Universality of the threshold for } \\
\text { complete consensus for the opinion dynamics of Def- } \\
\text { fuant et al. International Journal of Modern Physics C, } \\
15,1301-1307\end{array}$ & 6 \\
\hline Lorenz2007 & $\begin{array}{l}\text { LORENZ, J. (2007). Continuous opinion dynamics under } \\
\text { bounded confidence: A survey. International Journal of } \\
\text { Modern Physics C, (18), 1-20 }\end{array}$ & 5 \\
\hline Deffuant2002 & $\begin{array}{l}\text { DEFFUANT, G., Amblard, F., Weisbuch, G. \& Faure, T. } \\
\text { (2002). How can extremism prevail? A study on the rel- } \\
\text { ative agreement interaction model. Journal of Artificial } \\
\text { Societies and Social Simulation, 5(4), } 1\end{array}$ & 5 \\
\hline Nowak1990 & $\begin{array}{l}\text { NOWAK, A., Szamrej, J. \& Latané, B. (1990). From private } \\
\text { attitude to public opinion: A dynamic theory of social } \\
\text { impact. Psychological Review, } 97(3), 362-376\end{array}$ & 5 \\
\hline Sznajd-Weron2000 & $\begin{array}{l}\text { SZNAJD-WERON, K. \& Sznajd, J. (2000). Opinion evo- } \\
\text { lution in closed community. International Journal of } \\
\text { Modern Physics C, 11(6), 1157-1165 }\end{array}$ & 3 \\
\hline Weisbuch2002 & $\begin{array}{l}\text { WEISBUCH, G., Deffuant, G., Amblard, F. \& Nadal, J. P. } \\
\text { (2002). Meet, discuss, and segregate! Complexity, 7(3), } \\
\text { 55-63 }\end{array}$ & 3 \\
\hline
\end{tabular}




\begin{tabular}{|c|c|c|}
\hline Short citation & Publication & Number of links \\
\hline Watts1998 & $\begin{array}{l}\text { WATTS, D. J. \& Strogatz, S. H. (1998). Collective dynam- } \\
\text { ics of small-world networks. Nature, 393, 440-442 }\end{array}$ & 3 \\
\hline Nowak2006 & $\begin{array}{l}\text { NOWAK, M. A. (2006). Five rules for the evolution of co- } \\
\text { operation. Science, } 314,1560-1563\end{array}$ & 3 \\
\hline Hegselmann2002 & $\begin{array}{l}\text { HEGSELMANN, R. \& Krause, U. (2002). Opinion dynam- } \\
\text { ics and bounded confidence models: Analysis, and sim- } \\
\text { ulation. Journal of Artificial Societies and Social Simu- } \\
\text { lation, 5(3), } 2\end{array}$ & 2 \\
\hline Deffuant2006 & $\begin{array}{l}\text { DEFFUANT, G. (2006). Comparing extremism propaga- } \\
\text { tion patterns in continuous opinion models. Journal of } \\
\text { Artificial Societies and Social Simulation, } 9(3), 8\end{array}$ & 2 \\
\hline Epstein2008 & $\begin{array}{l}\text { EPSTEIN, J. M. (2008). Why Model? Journal of Artificial } \\
\text { Societies and Social Simulation, } 11(4), 12\end{array}$ & 2 \\
\hline Cohen1998 & $\begin{array}{l}\text { COHEN, M., Riolo, R. \& Axelrod, R. (1998). The emer- } \\
\text { gence of social organization in the Prisoner's Dilemma: } \\
\text { How context preservation and other factors promote } \\
\text { cooperation. Santa Fe Institute, Working Paper, 99-01- } \\
002\end{array}$ & 2 \\
\hline Amblard2004 & $\begin{array}{l}\text { AMBLARD, F. \& Deffuant, G. (2004). The role of network } \\
\text { topology on extremism propagation with the relative } \\
\text { agreement opinion dynamics. Physica A, } 343,725-738\end{array}$ & 2 \\
\hline Ben-Naim2003 & $\begin{array}{l}\text { BEN-NAIM, E., Krapivsky, P. L. \& REDNER, S. (2003). } \\
\text { Bifurcations and patterns in compromise processes. } \\
\text { Physica D, 183, 190-204 }\end{array}$ & 2 \\
\hline Hesse1963 & $\begin{array}{l}\text { HESSE, M. B. (1963). Models and Analogies in Science. } \\
\text { London: Sheed and Ward }\end{array}$ & 2 \\
\hline Newman2003 & $\begin{array}{l}\text { NEWMAN, M. E. J. \& Park, J. (2003). Why social networks } \\
\text { are different from other types of networks. Physical Re- } \\
\text { view E, } 68(3), 036122\end{array}$ & 1 \\
\hline
\end{tabular}

\begin{tabular}{|c|c|c|}
\hline Short citation & Publication & Number of links \\
\hline \multicolumn{3}{|c|}{ 1.1 Reciprocity (7 nodes, 26 links, density 0.619) } \\
\hline Boyd1988 & $\begin{array}{l}\text { BOYD, R. \& Richerson, P. J. (1988). The evolution of reci- } \\
\text { procity in sizeable groups. Journal of Theoretical Biol- } \\
\text { ogy, 132, 337-356 }\end{array}$ & 5 \\
\hline Roberts 2003 & $\begin{array}{l}\text { ROBERTS, G. \& Renwick, J. S. (2003). The development } \\
\text { of cooperative relationships: An experiment. Proceed- } \\
\text { ings of the Royal Society, 270, } 2279-2283\end{array}$ & 5 \\
\hline Wellman2006 & $\begin{array}{l}\text { WELLMAN, B., Hogan, B., Berg, K., Boase, J., Carrasco, } \\
\text { J.A., Côté, R.,...\& Tran, P. (2006). Connected lives: The } \\
\text { project. In Purcell, P. (Eds.) Networked Neighborhoods. } \\
\text { Berlin: Springer }\end{array}$ & 5 \\
\hline Nowak2005 & $\begin{array}{l}\text { NOWAK, M. A. \& Sigmund, K. (2005). Evolution of indi- } \\
\text { rect reciprocity. Nature, 437, 1291-1298 }\end{array}$ & 4 \\
\hline Kim2009 & $\begin{array}{l}\text { KIM, W.-S. (2009). Effects of trust on complex adap- } \\
\text { tive supply networks: An agent-based simulation study. } \\
\text { Journal of Artificial Societies and Social Simulation, } \\
\text { 13(3), } 4\end{array}$ & 4 \\
\hline Granovetter1973 & $\begin{array}{l}\text { GRANOVETTER, M. (1973). The strength of weak ties. } \\
\text { American Journal of Sociology, } 78,1360-1380\end{array}$ & 2 \\
\hline
\end{tabular}




\begin{tabular}{|c|c|c|}
\hline Short citation & Publication & Number of links \\
\hline Sutcliffe2012 & $\begin{array}{l}\text { SUTCLIFFE, A. \& Wang, D. (2012). Computational mod- } \\
\text { elling of trust and social relationships. Journal of Artifi- } \\
\text { cial Societies and Social Simulation, 15(1), } 3\end{array}$ & 1 \\
\hline \multicolumn{3}{|c|}{ 1.2 Evolution of Cooperation (16 nodes, 76 links, density 0.317 ) } \\
\hline Nowak2006 & $\begin{array}{l}\text { NOWAK, M. A. (2006). Five rules for the evolution of co- } \\
\text { operation. Science, } 314,1560-1563\end{array}$ & 9 \\
\hline Axelrod1981 & $\begin{array}{l}\text { AXELROD, R. \& Hamilton, W. D. (1981). The evolution of } \\
\text { cooperation. Science, 211, 1390-1396 }\end{array}$ & 9 \\
\hline Santos2006 & $\begin{array}{l}\text { SANTOS, F. C. \& Pacheco, J. M. (2006). A new route to } \\
\text { the evolution of cooperation. Journal of Evolutionary } \\
\text { Biology, } 19,726-733\end{array}$ & 7 \\
\hline Nowak1998 & $\begin{array}{l}\text { NOWAK, M. A. \& Sigmund, K. (1998). Evolution of indi- } \\
\text { rect reciprocity by image scoring. Nature, 393, 573-577 }\end{array}$ & 6 \\
\hline Hales2000 & $\begin{array}{l}\text { HALES, D. (2000). Cooperation without space or mem- } \\
\text { ory: Tags, groups and the prisoner's dilemma. Lecture } \\
\text { Notes in Computer Science, } 1979,157-166\end{array}$ & 6 \\
\hline Fehr2002 & $\begin{array}{l}\text { FEHR, E. \& Gächter, S. (2002). Altruistic punishment in } \\
\text { humans. Nature, 452, 348-351 }\end{array}$ & 6 \\
\hline Trivers1971 & $\begin{array}{l}\text { TRIVERS, R. L. (1971). The evolution of reciprocal altru- } \\
\text { ism. Quarterly Review of Biology, 46, 35-57 }\end{array}$ & 6 \\
\hline Riolo2001 & $\begin{array}{l}\text { RIOLO, R. L., Cohen, M. D. \& Axelrod, R. (2001). Evolution } \\
\text { of cooperation without reciprocity. Nature, } 414,441-443\end{array}$ & 5 \\
\hline Hamilton1964 & $\begin{array}{l}\text { HAMILTON, W. D. (1964). The genetical evolution of so- } \\
\text { cial behavior. Journal of Theoretical Biology, 37, 1-52 }\end{array}$ & 4 \\
\hline Fehr2000 & $\begin{array}{l}\text { FEHR, E. \& Gächter, S. (2000). Cooperation and punish- } \\
\text { ment in public goods experiments. American Economic } \\
\text { Review, } 90,980-994\end{array}$ & 4 \\
\hline Camerer2003 & $\begin{array}{l}\text { CAMERER, C. (2003). Behavioral Game Theory. New } \\
\text { York, NY: University Press Princeton }\end{array}$ & 3 \\
\hline Ohtsuki2006 & $\begin{array}{l}\text { OHTSUKI, H., Hauert, C., Lieberman, E. \& Nowak, M. A. } \\
\text { (2006). A simple rule for the evolution of cooperation } \\
\text { on graphs and social networks. Nature, 441, 502-505 }\end{array}$ & 2 \\
\hline Fehr1999 & $\begin{array}{l}\text { FEHR, E. \& Schmidt, K. M. (1999). A theory of fairness, } \\
\text { competition, and cooperation. Quarterly Journal of } \\
\text { Economics, 114, 817-868 }\end{array}$ & 1 \\
\hline Hammond2006 & $\begin{array}{l}\text { HAMMOND, R. A. \& Axelrod, R. (2006). The evolution of } \\
\text { ethnocentrism. Journal of Conflict Resolution, 50, 926- } \\
936\end{array}$ & 1 \\
\hline Kim2010 & $\begin{array}{l}\text { KIM, J.-W. (2010), A tag-based evolutionary Prisoner's } \\
\text { Dilemma game on networks with different topologies. } \\
\text { Journal of Artificial Societies and Social Simulation, } \\
\text { 13(3), } 2\end{array}$ & 1 \\
\hline \multicolumn{3}{|c|}{ Simulation of Science (3 nodes, 6 links, density 1.000) } \\
\hline Weisberg2009 & $\begin{array}{l}\text { WEISBERG, M. \& Muldoon, R. (2009). Epistemic land- } \\
\text { scapes and the division of cognitive labor. Philosophy } \\
\text { of Science, } 76(2), 225-252\end{array}$ & 2 \\
\hline Gilbert1997 & $\begin{array}{l}\text { GILBERT, N. (1997). A simulation of the structure of aca- } \\
\text { demic science. Sociological Research Online, } 2(2), 3\end{array}$ & 2 \\
\hline Hull1998 & $\begin{array}{l}\text { HULL, D. L. (1988). Science as a Process: An Evolution- } \\
\text { ary Account of the Social and Conceptual Development } \\
\text { of Science. Chicago, IL: University of Chicago Press }\end{array}$ & 2 \\
\hline
\end{tabular}




\begin{tabular}{|c|c|c|}
\hline Short citation & Publication & Number of links \\
\hline \multicolumn{3}{|c|}{3 Marriage Models (8 nodes, 36 links, density 0.643) } \\
\hline Hills2008 & $\begin{array}{l}\text { HILLS, T. \& Todd, P. M. (2008). Population hetero- } \\
\text { geneity and individual differences in an assortative } \\
\text { agent-based marriage and divorce model (MADAM) us- } \\
\text { ing search with relaxing expectations. Journal of Artifi- } \\
\text { cial Societies and Social Simulation, 11(4), } 5\end{array}$ & 6 \\
\hline Todd2005 & $\begin{array}{l}\text { TODD, P. M., Billari, F. C. \& Simao, J. (2005). Aggregate } \\
\text { age at marriage patterns from individual mate search } \\
\text { heuristics. Demography, } 42(3), 559-574\end{array}$ & 6 \\
\hline Ferguson1989 & $\begin{array}{l}\text { FERGUSON, T. S. (1989). Who solved the secretary prob- } \\
\text { lem? Statistical Science, 4(3), 282-289 }\end{array}$ & 5 \\
\hline Gale1962 & $\begin{array}{l}\text { GALE, D. \& Shapley, L. S. (1962). College admissions } \\
\text { and the stability of marriage. American Mathematical } \\
\text { Monthly, } 69(1), 9-15\end{array}$ & 5 \\
\hline Mumcu2008 & $\begin{array}{l}\text { MUMCU, A. \& Saglam, I. (2008). Marriage forma- } \\
\text { tion/dissolution and marital distribution in a two- } \\
\text { period economic model of matching with cooperative } \\
\text { bargaining. Journal of Artificial Societies and Social } \\
\text { Simulation, 11(4), } 3\end{array}$ & 5 \\
\hline Todd1999 & $\begin{array}{l}\text { TODD, P. M. \& Miller, G. F. (1999). From pride and prej- } \\
\text { udice to persuasion: Satisficing in mate search. In } \\
\text { Gigerenzer, G., Todd, P. \& ABC Research Group (Eds.), } \\
\text { Simple Heuristics That Make Us Smart, 287-308. New } \\
\text { York, NY: Oxford University Press }\end{array}$ & 5 \\
\hline Billari2007 & $\begin{array}{l}\text { BILLARI, F. C., Diaz, B. A., Fent, T. \& Prskawetz, A. (2007). } \\
\text { The "Wedding-Ring": An agent-based marriage model } \\
\text { based on social interaction. Demographic Research, } \\
17(3), 59-82\end{array}$ & 3 \\
\hline Eubank2004 & $\begin{array}{l}\text { EUBANK, S., Guclu, H., Kumar, V.S.A., Marathe, M.V., } \\
\text { Srinivasan, A., Toroczkai, Z. \& Wang, N. (2004). Mod- } \\
\text { elling disease outbreaks in realistic urban social net- } \\
\text { works. Nature, } 429,180-184\end{array}$ & 1 \\
\hline \multicolumn{3}{|c|}{4 Opinion Dynamics (17 nodes, 68 links, density 0.176) } \\
\hline Deffuant2000 & $\begin{array}{l}\text { DEFFUANT, G., Neau, D., Amblard, F. \& Weisbuch G. } \\
\text { (2000). Mixing beliefs among interacting agents. Ad- } \\
\text { vances in Complex Systems, 3, 87-98 }\end{array}$ & 9 \\
\hline Hegselmann2002 & $\begin{array}{l}\text { HEGSELMANN, R. \& Krause, U. (2002). Opinion dynam- } \\
\text { ics and bounded confidence: Models, analysis and sim- } \\
\text { ulation. Journal of Artificial Societies and Social Simu- } \\
\text { lation, 5(3), } 2\end{array}$ & 6 \\
\hline Deffuant2006 & $\begin{array}{l}\text { DEFFUANT, G. (2006). Comparing extremism propaga- } \\
\text { tion patterns in continuous opinion models. Journal of } \\
\text { Artificial Societies and Social Simulation, } 9(3), 8\end{array}$ & 5 \\
\hline Lorenz2007 & $\begin{array}{l}\text { LORENZ, J. (2007). Continuous opinion dynamics under } \\
\text { bounded confidence: A survey. International Journal of } \\
\text { Modern Physics C, (18), 1-20 }\end{array}$ & 5 \\
\hline Deffuant2002 & $\begin{array}{l}\text { DEFFUANT, G., Amblard, F., Weisbuch, G. \& Faure, T. } \\
\text { (2002). How can extremism prevail? A study based on } \\
\text { the relative agreement model. Journal of Artificial So- } \\
\text { cieties and Social Simulation, 5(4)1 }\end{array}$ & 5 \\
\hline Festinger1957 & $\begin{array}{l}\text { FESTINGER, L. (1957). A Theory of Cognitive Dissonance. } \\
\text { Stanford, CA: Stanford University Press }\end{array}$ & 5 \\
\hline Kozma2008 & $\begin{array}{l}\text { KOZMA, B. \& Barrat, A. (2008). Consensus formation on } \\
\text { adaptive networks. Physical Review E, } 77(1), 1-10\end{array}$ & 4 \\
\hline
\end{tabular}




\begin{tabular}{|c|c|c|}
\hline Short citation & Publication & Number of links \\
\hline Huet2008 & $\begin{array}{l}\text { HUET, S., Deffuant, G. \& Jager, W. (2008). A rejection } \\
\text { mechanism in } 2 \text { d bounded confidence provides more } \\
\text { conformity. Advances in Complex Systems, 11(4), 529- } \\
549\end{array}$ & 4 \\
\hline Jager2005 & $\begin{array}{l}\text { JAGER, W. \& Amblard, F. (2005). Uniformity, bipolariza- } \\
\text { tion and pluriformity captured as generic stylized be- } \\
\text { haviour with an agent-based simulation model of atti- } \\
\text { tude change. Computational \& Mathematical Organiza- } \\
\text { tion Theory, } 10(4), 295-303(9)\end{array}$ & 4 \\
\hline Urbig2003 & $\begin{array}{l}\text { URBIG, D. (2003). Attitude dynamics with limited ver- } \\
\text { balisation capabilities. Journal of Artificial Societies } \\
\text { and Social Simulation, 6(1), } 2\end{array}$ & 4 \\
\hline Ajzen1980 & $\begin{array}{l}\text { AJZEN, I.\&Fishbein, M. (1980). Understanding Attitudes } \\
\text { and Predicting Social Behavior. Englewood Cliffs, NJ: } \\
\text { Prentice-Hall }\end{array}$ & 4 \\
\hline Urbig2008 & $\begin{array}{l}\text { URBIG, D., Lorenz, J. \& Herzberg, H. (2008). Opinion } \\
\text { dynamics: The effect of the number of peers met at } \\
\text { once. Journal of Artificial Societies and Social Simula- } \\
\text { tion, } 11(2), 4\end{array}$ & 4 \\
\hline Granovetter1978 & $\begin{array}{l}\text { GRANOVETTER, M. (1978). Threshold models of collec- } \\
\text { tive behavior. American Journal of Sociology, 83, 1420- } \\
1443\end{array}$ & 2 \\
\hline Schwarz2009 & $\begin{array}{l}\text { SCHWARZ, N. \& Ernst, A. (2009). Agent-based modeling } \\
\text { of the diffusion of environmental innovations - An em- } \\
\text { pirical approach. Technological Forecasting and Social } \\
\text { Change, } 76(4), 497-511\end{array}$ & 2 \\
\hline Castellani2009 & $\begin{array}{l}\text { CASTELLANO, C., Fortunato, S. \& Loreto, V. (2009). Sta- } \\
\text { tistical physics of social dynamics. Reviews of Modern } \\
\text { Physics, } 81(2), 591-646\end{array}$ & 2 \\
\hline Davidsson2002 & $\begin{array}{l}\text { DAVIDSSON, P. (2002). Agent-based social simulation: } \\
\text { A computer science view. Journal of Artificial Societies } \\
\text { and Social Simulation, 5(1), } 7\end{array}$ & 2 \\
\hline McPherson2001 & $\begin{array}{l}\text { MCPHERSON, M., Smith-Lovin, L. \& Cook, J. M. (2001). } \\
\text { Birds of a feather: Homophily in social networks. An- } \\
\text { nual Review of Sociology, } 27,415-444\end{array}$ & 1 \\
\hline \multicolumn{3}{|c|}{5 Standards (8 nodes, 32 links, density 0.571) } \\
\hline Polhill2008 & $\begin{array}{l}\text { POLHILL, J. G., Parker, D., Brown, D. \& Grimm, V. (2008). } \\
\text { Using the ODD protocol for describing three agent- } \\
\text { based social simulation models of land-use change. } \\
\text { Journal of Artificial Societies and Social Simulation, } \\
11(2), 3\end{array}$ & 6 \\
\hline Chater2006 & $\begin{array}{l}\text { CHATER, N. \& Manning, C. D. (2006). Probabilistic mod- } \\
\text { els of language processing and acquisition. Trends in } \\
\text { Cognitive Sciences, } 10(7), 335-344\end{array}$ & 5 \\
\hline Grimm2010 & $\begin{array}{l}\text { GRIMM, V., Berger, U., DeAngelis, D. L., Polhill, J. G., } \\
\text { Giske, J. \& Railsback, S. F. (2010). The ODD protocol: A } \\
\text { review and first update. Ecological Modelling, 221, 2760- } \\
2768\end{array}$ & 4 \\
\hline Grimm2005 & $\begin{array}{l}\text { GRIMM, V. \& Railsback, S. F. (2005). Individual-Based } \\
\text { Modeling and Ecology. Princeton, NJ: Princeton Univer- } \\
\text { sity Press }\end{array}$ & 3 \\
\hline Squazzoni2012 & $\begin{array}{l}\text { SQUAZZONI, F. (2012). Agent-Based Computational So- } \\
\text { ciology. West Sussex, UK: John Wiley \& Sons }\end{array}$ & 3 \\
\hline
\end{tabular}




\begin{tabular}{|c|c|c|}
\hline Short citation & Publication & Number of links \\
\hline Ramanath2004 & $\begin{array}{l}\text { RAMANATH, A. M. \& Gilbert, N. (2004). The design of } \\
\text { participatory agent-based social simulations. Journal } \\
\text { of Artificial Societies and Social Simulation, } 7(4), 1\end{array}$ & 3 \\
\hline Grimm2006 & $\begin{array}{l}\text { GRIMM, V., Berger, U., Bastiansen, F.,..., DeAngelis, D. L. } \\
\text { (2006). A standard protocol for describing individual- } \\
\text { based and agent-based models. Ecological Modelling, } \\
198(1-2), 115-126\end{array}$ & 2 \\
\hline Liu2007 & $\begin{array}{l}\text { LIU, J., Dietz, T., Carpenter,. S. R.,..., Taylor, W.W. (2007). } \\
\text { Complexity of coupled human and natural systems. Sci- } \\
\text { ence, 317, 1513-1516 }\end{array}$ & 2 \\
\hline Gilbert2007 & $\begin{array}{l}\text { GILBERT, N. (2007). Agent-Based Models. Los Angeles, } \\
\text { CA: Sage }\end{array}$ & 1 \\
\hline Lorscheid2012 & $\begin{array}{l}\text { LORSCHEID, I., Heine, B.-O. \& Meyer, M. (2012). Opening } \\
\text { the 'Black Box' of simulations: Increased transparency } \\
\text { and effective communication through the systematic } \\
\text { design of experiments. Computational and Mathemati- } \\
\text { cal Organization Theory, 18(1), 22-62 }\end{array}$ & 1 \\
\hline Kim2011 & $\begin{array}{l}\text { KIM, S.-Y. (2011). A model of political judgment: An } \\
\text { agent-based simulation of candidate evaluation. Jour- } \\
\text { nal of Artificial Societies and Social Simulation, 14(2), } 3\end{array}$ & 1 \\
\hline Wilensky1999 & $\begin{array}{l}\text { WILENSKY, U. (1999). NetLogo. Evanston, IL: Center } \\
\text { for Connected Learning and Computer-Based Model- } \\
\text { ing. Northwestern University }\end{array}$ & 1 \\
\hline \multicolumn{3}{|c|}{ 6.1 Methodology (Replication, Validation, Verification, etc.) (12 nodes, 26 links, density 0.199) } \\
\hline Axelrod1997 & $\begin{array}{l}\text { AXELROD, R. (1997). Advancing the art of simulation } \\
\text { in the social sciences. In Conte, R., Hegselmann, R. \& } \\
\text { Terna, P. (Eds.) Simulating Social Phenomena, 21-40. } \\
\text { Berlin: Springer }\end{array}$ & 5 \\
\hline Heath2009 & $\begin{array}{l}\text { HEATH, B., Hill, R. \& Ciarallo, F. (2009). A survey of } \\
\text { agent-based modeling practices (January } 1998 \text { to July } \\
\text { 2008). Journal of Artificial Societies and Social Simula- } \\
\text { tion, 12(4), } 9\end{array}$ & 4 \\
\hline Edmonds2003 & $\begin{array}{l}\text { EDMONDS, B. \& Hales, D. (2003). Replication, replica- } \\
\text { tion and replication: Some hard lessons from model } \\
\text { alignment. Journal of Artificial Societies and Social } \\
\text { Simulation, 6(4), } 11\end{array}$ & 3 \\
\hline Gilbert1999 & $\begin{array}{l}\text { GILBERT, G. N. \& Troitzsch, K. G. (1999). Simulation for } \\
\text { the Social Scientist. Buckingham, UK and Philadelphia, } \\
\text { PA: Open University Press }\end{array}$ & 2 \\
\hline Wilensky2007 & $\begin{array}{l}\text { WILENSKY, U. \& Rand, W. (2007). Making models match: } \\
\text { Replicating an agent-based model. Journal of Artificial } \\
\text { Societies and Social Simulation, 10(4), } 2\end{array}$ & 2 \\
\hline Edmonds2005 & $\begin{array}{l}\text { EDMONDS, B. \& Moss, S. (2005). From KISS to KIDS: An } \\
\text { 'anti-simplistic' modelling approach. Lecture Notes in } \\
\text { Computer Science, 34(15), 130-144 }\end{array}$ & 2 \\
\hline Meyer2011 & $\begin{array}{l}\text { MEYER, M., Zaggl, M. A. \& Carley, K. M. (2011). Measur- } \\
\text { ing CMOT's intellectual structure and its development. } \\
\text { Computational and Mathematical Organization Theory, } \\
\text { 17(1), 1-34 }\end{array}$ & 2 \\
\hline Richiardi2006 & $\begin{array}{l}\text { RICHIARDI, M., Leombruni, R., Saam, N. \& Sonnessa, M. } \\
\text { (2006). A common protocol for describing agent-based } \\
\text { models. Journal of Artificial Societies and Social Simu- } \\
\text { lation, 9(1), } 15\end{array}$ & 2 \\
\hline
\end{tabular}




\begin{tabular}{|c|c|c|}
\hline Short citation & Publication & Number of links \\
\hline Gilbert2000 & $\begin{array}{l}\text { GILBERT, G. N. \& Terna, P. (2000). How to build and use } \\
\text { agent-based models in social science. Mind \& Society, } \\
1(1), 57-72\end{array}$ & 1 \\
\hline March1991 & $\begin{array}{l}\text { MARCH, J. G. (1991). Exploration and exploitation in or- } \\
\text { ganizational learning. Organization Science, } 2 \text { (1), } 71-87\end{array}$ & 1 \\
\hline Zinn2009 & $\begin{array}{l}\text { ZINN, S., Himmelspach, J., Gampe, J. \& Uhrmacher, A. } \\
\text { M. (2009). MIC-CORE: A Tool for Microsimulation. Winter } \\
\text { Simulation Conference, Austin, Texas, USA }\end{array}$ & 1 \\
\hline Meyer2009 & $\begin{array}{l}\text { MEYER, M., Lorscheid, I. \& Troitzsch, K. G. (2009). The } \\
\text { development of social simulation as reflected in the } \\
\text { first ten years of JASSS: A citation and co-citation analy- } \\
\text { sis. Journal of Artificial Societies and Social Simulation, } \\
4(12), 12\end{array}$ & 1 \\
\hline \multicolumn{3}{|c|}{ 6.2 Tools and Platforms (9 nodes, 24 links, density 0.333} \\
\hline Tobias2004 & $\begin{array}{l}\text { TOBIAS, R. \& Hofmann, C. (2004). Evaluation of free } \\
\text { Java-libraries for social-scientific agent-based simula- } \\
\text { tion. Journal of Artificial Societies and Social Simula- } \\
\text { tion, } 7(1), 6\end{array}$ & 5 \\
\hline Nikolai2009 & $\begin{array}{l}\text { NIKOLAI, C. \& Madey, G. (2009). Tools of the trade: A sur- } \\
\text { vey of various agent-based modeling platforms. Jour- } \\
\text { nal of Artificial Societies and Social Simulation, 12(2), } 2\end{array}$ & 4 \\
\hline Etienne2011 & $\begin{array}{l}\text { ETIENNE, M. (2011). Companion Modelling. A Partici- } \\
\text { patory Approach to Support Sustainable Development. } \\
\text { Versailles, France: QUAE }\end{array}$ & 3 \\
\hline Railsback2006 & $\begin{array}{l}\text { RAILSBACK, S., Lytinen, S. \& Jackson, S. (2006). Agent- } \\
\text { based simulation platforms: Review and development } \\
\text { recommendations. Simulation, 82(9), 609-22 }\end{array}$ & 3 \\
\hline Gllbert2002 & $\begin{array}{l}\text { GILBERT, N. \& Bankes, S. (2002). Platforms and methods } \\
\text { for agent-based modeling. Proceedings of the National } \\
\text { Academy of Sciences of the United States of America, } \\
99(3), 7197-8\end{array}$ & 3 \\
\hline Bousquet1998 & $\begin{array}{l}\text { BOUSQUET, F., Bakam, I., Protonand, H. \& Le Page, C. } \\
\text { (1998). Cormas: Common-pool resources and multi- } \\
\text { agent systems. In IEA/AIE '98 Proceedings of the 11th } \\
\text { International Conference on Industrial and Engineer- } \\
\text { ing Applications of Artificial Intelligence and Expert Sys- } \\
\text { tems: Tasks and Methods in Applied Artificial Intelli- } \\
\text { gence. Berlin: Springer, } 826-837\end{array}$ & 2 \\
\hline Luke2005 & $\begin{array}{l}\text { LUKE, A., Cioffi-Revilla, C., Panait, L., Sullivan, K. \& } \\
\text { Balan, G. (2005). MASON: A multiagent simulation en- } \\
\text { vironment. Simulation, 81(7), 517-527 }\end{array}$ & 1 \\
\hline Barreteau2003 & $\begin{array}{l}\text { BARRETEAU, O. \& others (2003). Our companion mod- } \\
\text { elling approach. Journal of Artificial Societies and So- } \\
\text { cial Simulation, } 6(2), 1\end{array}$ & 1 \\
\hline Bousquet2004 & $\begin{array}{l}\text { BOUSQUET, F. \& Le Page, C. (2004). Multi-agent simula- } \\
\text { tions and ecosystem management: A review. Ecological } \\
\text { Modelling, 176, 313-332 }\end{array}$ & 1 \\
\hline Minar1996 & $\begin{array}{l}\text { MINAR, N., Burkhart, R., Langton, C. \& Askenazi, M. } \\
\text { (1996). The swarm simulation system: A toolkit for } \\
\text { building multi-agent simulations. Working Paper 96- } \\
\text { 06-042. Santa Fe: Santa Fe Institute }\end{array}$ & 1 \\
\hline
\end{tabular}

Table 6: Period 2011-08/2014 


\section{Appendix B: Link Strength between Groups}

\begin{tabular}{llll}
\hline Linked groups & $\begin{array}{l}\text { Number of } \\
\text { possible } \\
\text { links }\end{array}$ & $\begin{array}{l}\text { Aggregated } \\
\text { CoCit } \\
\text { score }\end{array}$ & $\begin{array}{l}\text { GroupCoCit } \\
\text { Score }\end{array}$ \\
& 143 & 0.93 & 0.65 \\
\hline 1.2 Norms-1.6 Replication & 195 & 5.08 & 2.6 \\
1.2 Norms-1.1 Learning in Social Dilemmas & 117 & 0.85 & 0.72 \\
1.2 Norms-1.4 Validation & 78 & 0.33 & 0.42 \\
1.2 Norms-1.3 Modeling & 182 & 0.36 & 0.2 \\
1.2 Norms-1.7 Evolution & 208 & 0.65 & 0.31 \\
1.2 Norms-2 Opinion Dynamics & 104 & 0.77 & 0.74 \\
1.2 Norms-1.5 Environmental Aspects & 165 & 8.65 & 5.24 \\
1.6 Replication-1.1 Learning in Social Dilemmas & 99 & 1.4 & 1.42 \\
1.6 Replication-1.4 Validation & 66 & 2.45 & 3.71 \\
1.6 Replication-1.3 Modeling & 154 & 3.37 & 2.19 \\
1.6 Replication-1.7 Evolution & 176 & 0.19 & 0.11 \\
1.6 Replication-2 Opinion Dynamics & 88 & 5.48 & 6.23 \\
1.6 Replication-1.5 Environmental Aspects & 135 & 2.97 & 2.2 \\
1.1 Learning in Social Dilemmas-1.4 Validation & 90 & 7.32 & 8.13 \\
1.1 Learning in Social Dilemmas-1.3 Modeling & 210 & 4.37 & 2.08 \\
1.1 Learning in Social Dilemmas-1.7 Evolution & 240 & 1.17 & 0.49 \\
1.1 Learning in Social Dilemmas-2 Opinion Dynamics & 120 & 4.89 & 4.07 \\
1.1 Learning in Social Dilemmas-1.5 Environmental Aspects & 54 & 1.53 & 2.83 \\
1.4 Validation-1.3 Modeling & 126 & 0.36 & 0.28 \\
1.4 Validation-1.7 Evolution & 144 & 1.42 & 0.98 \\
1.4 Validation-2 Opinion Dynamics & 72 & 3.73 & 5.18 \\
1.4 Validation-1.5 Environmental Aspects & 84 & 0.84 & 1 \\
1.3 Modeling-1.7 Evolution & 96 & 0.54 & 0.56 \\
1.3 Modeling-2 Opinion Dynamics & 48 & 0.97 & 2.02 \\
1.3 Modeling-1.5 Environmental Aspects & 224 & 0.49 & 0.22 \\
1.7 Evolution-2 Opinion Dynamics & 112 & 0.61 & 0.55 \\
1.7 Evolution-1.5 Environmental Aspects & 128 & 0.22 & 0.17 \\
2 Opinion Dynamics-1.5 Environmental Aspects & & $\mathbf{2 8}$ & $\mathbf{2 8}$ \\
\hline N & & $\mathbf{0 . 9 7}$ & $\mathbf{0 . 9 9}$ \\
Median & & $\mathbf{2 . 1 3}$ & $\mathbf{1 . 9 8}$ \\
Average & & $\mathbf{0 . 7 8}$ \\
Kendall's tau (significant at the 0.01 level, 2-tailed) & & & \\
\hline & & & \\
\hline
\end{tabular}

Table 7: Period 2008-07/2011 [We tested the correlation of the conjoint CoCit scores and the GroupCoCit scores. We identified no correlation between the GroupCoCit scores and the size of groups]. 


\begin{tabular}{llll}
\hline Linked groups & $\begin{array}{l}\text { Number of } \\
\text { possible } \\
\text { links }\end{array}$ & $\begin{array}{l}\text { Aggregated } \\
\text { CoCit } \\
\text { score }\end{array}$ & $\begin{array}{l}\text { GroupCoCit } \\
\text { Score }\end{array}$ \\
\hline 2 Simulation of Science-5 Standards & 36 & 0.03 & 0.09 \\
2 Simulation of Science-3 Marriage Models & 24 & 0 & 0 \\
2 Simulation of Science-1.2 Evolution of Cooperation & 48 & 0 & 0 \\
2 Simulation of Science-6.2 Tools and Platforms & 30 & 0 & 0 \\
2 Simulation of Science-6.1 Methodology & 36 & 0.12 & 0.33 \\
2 Simulation of Science-1.1 Reciprocity & 21 & 0 & 0 \\
2 Simulation of Science-4 Opinion Dynamics & 51 & 0 & 0 \\
5 Standards-3 Marriage Models & 96 & 0.61 & 0.64 \\
5 Standards-1.2 Evolution of Cooperation & 192 & 0.27 & 0.14 \\
5 Standards-6.2 Tools and Platforms & 120 & 1.35 & 1.13 \\
5 Standards-6.1 Methodology & 144 & 2.92 & 2.03 \\
5 Standards-1.1 Reciprocity & 84 & 0.48 & 0.58 \\
5 Standards-4 Opinion Dynamics & 204 & 0.55 & 0.27 \\
3 Marriage Models-1.2 Evolution of Cooperation & 128 & 0.29 & 0.22 \\
3 Marriage Models-6.2 Tools and Platforms & 80 & 0.06 & 0.07 \\
3 Marriage Models-6.1 Methodology & 96 & 0.42 & 0.44 \\
3 Marriage Models-1.1 Reciprocity & 56 & 0.16 & 0.28 \\
3 Marriage Models-4 Opinion Dynamics & 136 & 1.46 & 1.07 \\
1.2 Evolution of Cooperation-6.2 Tools and Platforms & 160 & 0.59 & 0.37 \\
1.2 Evolution of Cooperation-6.1 Methodology & 192 & 0.83 & 0.43 \\
1.2 Evolution of Cooperation-1.1 Reciprocity & 112 & 3.11 & 2.77 \\
1.2 Evolution of Cooperation-4 Opinion Dynamics & 272 & 0 & 0 \\
6.2 Tools and Platforms-6.1 Methodology & 120 & 2.57 & 2.14 \\
6.2 Tools and Platforms-1.1 Reciprocity & 70 & 0.14 & 0.2 \\
6.2 Tools and Platforms-4 Opinion Dynamics & 170 & 0.02 & 0.01 \\
6.2 Tools and Platforms -1.1 Reciprocity & 84 & 0.46 & 0.55 \\
6.1 Methodology-4 Opinion Dynamics & 204 & 0.37 & 0.18 \\
1.1 Reciprocity-4 Opinion Dynamics & 119 & 0.82 & 0.69 \\
\hline N & & $\mathbf{2 8}$ & $\mathbf{2 8}$ \\
Median & & $\mathbf{0 . 3 3}$ & $\mathbf{0 . 2 6}$ \\
Average & & $\mathbf{0 . 6 3}$ & $\mathbf{0 . 5 2}$ \\
Kendall's tau (significant at the 0.01 level, 2-tailed) & & $\mathbf{0 . 8 5}$ \\
\hline & & & \\
\hline
\end{tabular}

Table 8: Period 2011-08/2014 [We tested the correlation of the conjoint CoCit scores and the GroupCoCit scores. We identified no correlation between the GroupCoCit scores and the size of groups]. 


\section{Appendix C: Co-Citation Network Metrics}

\begin{tabular}{lcccc}
\hline & \multicolumn{2}{c}{ Meyer et al. (2009) } & \multicolumn{2}{c}{ This study } \\
\cline { 2 - 5 } & $1998-2002$ & $2003-207$ & 2008-07/2011 & 08/2011-2014 \\
\hline Number of clusters per network & 2 & 7 & 2 & 6 \\
Number of clusters per network & 6 & 12 & 8 & 8 \\
Number of nodes per network & 48 & 123 & 92 & 80 \\
Number of links per network & 124 & 386 & 363 & 294 \\
Network density & 0.05 & 0.03 & 0.04 & 0.05 \\
Median (nodes per group) & 9 & 9 & 12 & 9 \\
Standard deviation (nodes per group) & 1.6 & 2.74 & 3.35 & 4.42 \\
Median (links per group) & 19 & 28 & 47 & 29 \\
Standard deviation (links per group) & 8.06 & 16.88 & 26.17 & 2.02 \\
Median (group density) & 0.37 & 0.41 & 0.35 & 0.45 \\
Standard deviation (group density) & 0.11 & 0.13 & 0.09 & 0.26 \\
\hline
\end{tabular}

Table 9: Co-Citation Network Metrics

\section{Notes}

${ }^{1}$ See http://jasss.soc.surrey.ac.uk/index_by_issue.html

${ }^{2}$ Here, an html parser implemented in JAVA was applied, which was also used by Meyer et al. (2009). Articles not available in html format were added manually.

${ }^{3}$ First, we checked the CSV file with random samples for completeness to check whether all articles and references had been recorded by the parser. Subsequently, one of us did an exhaustive correction of inconsistencies in the CSV file, which resulted from different citation styles, italic letters, word wraps, and incorrect citations in the original html files.

${ }^{4}$ We subdivided the total number of published articles in 2011 as follows. The period until $07 / 2011$ includes all 23 articles of volumes 14(1), 14(2), and 14(3). The remaining volume 14(4) includes 22 articles and thus a similar number of articles. Volume 14(3) was published on 03-Jul-2011.

${ }^{5}$ The publications included in the ranking are defined by the share of citations. We determined a share that results in a ranking of length that is comparable to the first study. There should be no publications left out of the ranking that have the same number of citations. We did not include more than 13 publications, as there are several publications that follow the 13 most cited sources in their share of citations, so that the list would be too long.

${ }^{6}$ The book Simulation for the Social Scientist of Gilbert and Troitzsch was originally published in 1999. A second edition was published in 2005. In our study, we refer with references of 2005 to both published editions.

${ }^{7}$ Given the 20 NetLogo citations divided by the 165 articles published in JASSS from 08/2011 to 2014.

${ }^{8}$ The category "journal" also includes peer-reviewed e-journals. The category "working paper" includes all citations with the key words of working paper, mimeo, discussion paper, position paper, and research report. The category "proceeding paper" includes paper citations with attached pdf links and the key words of symposium, conference, and workshop. The category "miscellaneous" includes all citations that could not clearly be assigned to a category such as statistical reports, technical papers, technical reports, newspaper articles, and unpublished conference talks.

${ }^{9}$ The sensitivity of $H H I$ to $N$, allows only for a comparison with studies with a similar $N$. We use the index here mainly to analyze the diversity between the time periods.

${ }^{10} \mathrm{~A}$ direct comparison of the results of this analysis with those of the previous study (Meyer et al.|2009) would be limited due to substantial changes in terms of journal classifications in the Thomson Reuters SCII/ISI. Therefore, we also re-categorized the data of the first study by using the list "Essential Science Indicators Subject Areas" to make the results comparable. 
${ }^{11}$ The result of the subject field analysis is limited by the validity of the journal classification by Thomson Reuters. Scientific subject fields are often ill-defined and blurry. Journals can represent an intersection of articles, which can be related to different subjects. For this reason, the classification is ambiguous Bensman \& Leydesdorff 2009). For a detailed analysis of inward and outward citations, their interrelations, and the bibliographic impact of JASSS publications on certain research domains, see Squazzoni \& Casnici (2013).

${ }^{12}$ The network mapping and network colors of nodes and links are based on the function "Newman Grouping" provided by the used tool Organizational Risk Analyser (ORA). This function is based on the Newman Algorithm, which is recommended for identifying distinct groups within clusters (Carley et al.2010, Clauset et al. 2004).

${ }^{13}$ To label the identified groups, we started with sources at the center of a cluster, which have the highest number of links in a cluster. To validate our decisions, we discussed the labels with a number of experts. For additional feedback, the results were presented to several international conference and seminar audiences.

${ }^{14}$ Network density was calculated as the number of edges divided by the number of possible edges not including self-references as follows: $2 *$ number of edges/(number of nodes $*($ number of nodes-1)) (lacobucci 1994). One visible link corresponds mathematically to two edges given the bidirectionality of links. All the measurements of the groups are listed in Appendix A

${ }^{15} \mathrm{~A}$ closer look at the publication provides further evidence that homophily is relevant for both research issues. For opinion dynamics, the article describes "... homophily effects in who we consider to be the relevant others in our organizational environment: those to whom we compare ourselves, those whose opinions we attend to..." (McPherson et al.|2001, p. 428). Homophily also effects marriage formation because "... the homophily principle structures network ties of every type, including marriage ..." (McPherson et al.|2001, p. 415).

${ }^{16}$ Looking at Figure 9, one has to consider that there is an unbalanced number of co-citations from period 1 (1998-2002) to period 2 (2003-2008). This limitation of the previous study was discussed in Section 3 . The above-average data set size in period 2 increases the probability that more groups emerge. The greater a group, the more robust is its emergence to different sample sizes. Hence, regarding the smaller groups in period 2, the longitudinal comparison is limited. This is incorporated into the interpretation, which focusses on the main groups.

\section{References}

Allmayer, S. \& Winkler, H. (2013). Interface management research in supplier-customer relationships: Findings from a citation analysis of international literature. Journal of Business Economics, 83(9), 1015-1061

Axelrod, R. (2006). The Evolution of Cooperation. New York, NY: Basic Books

Axelrod, R. \& Hamilton, W. (1981). The evolution of cooperation. Science, 211(4489), 1390-1396

Axtell, R. (2000). Why agents? On the varied motivations for agent computing in the social sciences. In C. M. Macal \& D. Sallach (Eds.), Proceedings of the Workshop on Agent Simulation: Applications, Models, and Tools, (pp. 3-24). Argonne, IL: Argonne National Laboratory

Backhaus, K., Lügger, K. \& Koch, M. (2011). The structure and evolution of business-to-business marketing: a citation and co-citation analysis. Industrial Marketing Management, 40(6), 940-951

Bensman, S. J. \& Leydesdorff, L. (2009). Definition and identification of journals as bibliographic and subject entities: Librarianship versus ISI Journal Citation Reports methods and their effect on citation measures. Journal of the American Society for Information Science and Technology, 60(6), 1097-1117

Bersini, H. (2012). UML for ABM. Journal of Artificial Societies and Social Simulation, 15(1), 9

Bornmann, L. \& Daniel, H.-D. (2008). What do citation counts measure? A review of studies on citing behavior. Journal of Documentation, 64(1), 45-80

Carley, K. M., Pfeffer, J., Reminga, J., Storrick, J. \& Columbus, D. (2010). ORA user's guide 2010. Tech. rep., DTIC Document

Chi, P.-S. (2016). Differing disciplinary citation concentration patterns of book and journal literature? Journal of Informetrics, 10(3), 814-829 
Clauset, A., Newman, M. E. \& Moore, C. (2004). Finding community structure in very large networks. Physical review $E, 70(6), 066111$

Davidsson, P. (2002). Agent based social simulation: A computer science view. Journal of Artificial Societies and Social Simulation, 5(1), 7

Edmonds, B. \& Hales, D. (2003). Replication, replication and replication: Some hard lessons from model alignment. Journal of Artificial Societies and Social Simulation, 6(4), 11

Epstein, J. M. (1999). Agent-based computational models and generative social science. Complexity, 4(5), 41-60

Epstein, J. M. \& Axtell, R. (1996). Growing Artificial Societies: Social Science from the Bottom Up. Washington, DC: Brookings Institution Press

Fioretti, G. (2013). Agent-based simulation models in organization science. Organizational Research Methods, $16(2), 227-242$

García-Lillo, F., Úbeda García, M. \& Marco-Lajara, B. (2016). The intellectual structure of research in hospitality management: A literature review using bibliometric methods of the journal International Journal of Hospitality Management. International Journal of Hospitality Management, 52, 121-130

Gilbert, N. (2008). Agent-Based Models. London: Sage

Gilbert, N. \& Troitzsch, K. (2005). Simulation for the Social Scientist (second ed.). New York, NY: McGraw-Hill International

Gipp, B. \& Beel, J. (2009). Citation proximity analysis (CPA: A new approach for identifying related work based on Co-Citation Analysis. In Proceedings of the 12th International Conference on Scientometrics and Informetrics (ISSIâĂŹo9), vol. 2, (pp. 571-575). Rio de Janeiro (Brazil): International Society for Scientometrics and Informetrics

Gmür, M. (2003). Co-citation analysis and the search for invisible colleges: A methodological evaluation. Scientometrics, 57(1), 27-57

Greene, D., Freyne, J., Smyth, B. \& Cunningham, P. (2008). An analysis of research themes in the CBR conference literature. In European Conference on Case-Based Reasoning, (pp. 18-43). Berlin/Heidelberg: Springer

Grimm, V., Berger, U., Bastiansen, F., Eliassen, S., Ginot, V., Giske, J., Goss-Custard, J., Grand, T., Heinz, S. K., Huse, G., Huth, A., Jepsen, J. U., Jørgensen, C., Mooij, W. M., Müller, B., Pe'er, G., Piou, C., Railsback, S. F., Robbins, A. M., Robbins, M. M., Rossmanith, E., Rüger, N., Strand, E., Souissi, S., Stillman, R. A., Vabø, R., Visser, U. \& DeAngelis, D. L. (2006). A standard protocol for describing individual-based and agent-based models. Ecological Modelling, 198(1), 115-126

Grimm, V., Berger, U., DeAngelis, D. L., Polhill, J. G., Giske, J. \& Railsback, S. F. (2010). The ODD protocol: a review and first update. Ecological Modelling, 221(23), 2760-2768

lacobucci, D. (1994). Graphs and matrices. In S. Wasserman \& K. Faust (Eds.), Social Network Analysis: Methods and Applications, (pp. 92-166). Cambridge: Cambridge University Press

Izquierdo, S. S., Izquierdo, L. R. \& Gotts, N. M. (2008). Reinforcement learning dynamics in social dilemmas. Journal of Artificial Societies and Social Simulation, 11(2), 1

JASSS (2015). Journal of artificial societies and social simulation

Ke, Q., Ferrara, E., Radicchi, F. \& Flammini, A. (2015). Defining and identifying Sleeping Beauties in science. Proceedings of the National Academy of Sciences, 112(24), 7426-7431

Le Page, C., Becu, N., Bommel, P. \& Bousquet, F. (2012). Participatory agent-based simulation for renewable resource management: The role of the Cormas simulation platform to nurture a community of practice. Journal of Artificial Societies and Social Simulation, 15(1), 10

Leitner, S. \& Wall, F. (2015). Simulation-based research in management accounting and control: An illustrative overview. Journal of Management Control, 26(2-3), 105-129

McPherson, M., Smith-Lovin, L. \& Cook, J. M. (2001). Birds of a feather: Homophily in social networks. Annual Review of Sociology, 27(1), 415-444 
Meyer, M., Lorscheid, I. \& Troitzsch, K. G. (2009). The development of social simulation as reflected in the first ten years of JASSS: A citation and co-citation analysis. Journal of Artificial Societies and Social Simulation, $12(4), 12$

Meyer, M., Schäffer, U. \& Gmür, M. (2008). Transfer und austausch von wissen in der accounting-forschung: Eine zitations- und kozitationsanalyse englischsprachiger accounting-journals 1990-2004. Schmalenbachs Zeitschrift für betriebswirtschaftliche Forschung, 60(2), 153-181

Meyer, M., Zaggl, M. A. \& Carley, K. M. (2011). Measuring CMOT's intellectual structure and its development. Computational and Mathematical Organization Theory, 17(1), 1-34

Moqri, M., Bandyopadhyay, S. \& Kitchens, B. (2011). Knowledgemap, an automated classification of research areas in a scientific discipline. Workshop of Information Technology and Systems, Auckland, 2014

Mustafee, N., Katsaliaki, K. \& Fishwick, P. (2014a). Exploring the modelling and simulation knowledge base through journal co-citation analysis. Scientometrics, 98(3), 2145-2159

Mustafee, N., Katsaliaki, K. \& Fishwick, P. (2014b). A journal profiling and co-citation study of SIMULATION: The transactions of the society for modeling and simulation international. In Proceedings of the 2014 Annual Simulation Symposium, (p. 18). San Diego, CA: Society for Computer Simulation International

Nowak, M. A. (2006). Five rules for the evolution of cooperation. Science, 314(5805), 1560-1563

Osareh, F. (1996a). Bibliometrics, citation analysis and co-citation analysis: A review of literature i. Libri, 46(3), $149-158$

Osareh, F. (1996b). Bibliometrics, citation analysis and co-citation analysis: A review of literature ii. Libri, 46(4), $217-225$

Pan, R. K., Petersen, A. M., Pammolli, F. \& Fortunato, S. (2016). The memory of science: Inflation, myopia, and the knowledge network. arXiv preprint arXiv:1607.05606

Parolo, P. D. B., Pan, R. K., Ghosh, R., Huberman, B. A., Kaski, K. \& Fortunato, S. (2015). Attention decay in science. Journal of Informetrics, 9(4), 734-745

Polhill, G., Izquierdo, L. \& Gotts, N. (2004). The ghost in the model (and other effects of floating point arithmetic). Journal of Artificial Societies and Social Simulation, 8(1), 5

Radicchi, F. \& Castellano, C. (2012). Testing the fairness of citation indicators for comparison across scientific domains: The case of fractional citation counts. Journal of Informetrics, 6(1), 121-130

Railsback, S. F. \& Grimm, V. (2011). Agent-Based and Individual-Based Modeling: A Practical Introduction. Princeton, NJ: Princeton University Press

Schäffer, U., Nevries, P., Fikus, C. \& Meyer, M. (2011). Is finance research a 'normal science'? A bibliometric study of the structure and development of finance research from 1988 to 2007. Schmalenbach Business Review, 63, 189-225

Schmalensee, R. (1977). Using the H-Index of concentration with published data. The Review of Economics and Statistics, (pp. 186-193)

Schwarz, N., Kahlenberg, D., Haase, D. \& Seppelt, R. (2012). ABMland - A tool for agent-based model development on urban land use change. Journal of Artificial Societies and Social Simulation, 15(2), 8

Secchi, D. \& Seri, R. (2016). Controlling for false negatives in agent-based models: A review of power analysis in organizational research. Computational and Mathematical Organization Theory, 22, 1-28

SimSoc (2015). S SimSoc mailing list managed by jiscm@il. doi:https://www.jiscmail.ac.uk/cgi-bin/ webadmin?A $0=$ SIMSOC

Small, H. (1973). Co-citation in the scientific literature: A new measure of the relationship between two documents. Journal of the Association for Information Science and Technology, 24(4), 265-269

Squazzoni, F. (2010). The impact of agent-based models in the social sciences after 15 years of incursions. History of Economic Ideas, 18(2), 197-233 
Squazzoni, F. \& Casnici, N. (2013). Is social simulation a social science outstation? A bibliometric analysis of the impact of jasss. Journal of Artificial Societies and Social Simulation, 16(1), 10

Squazzoni, F., Jager, W. \& Edmonds, B. (2014). Social simulation in the social sciences: A brief overview. Social Science Computer Review, 32(3), 279-294

Thiele, J. C., Kurth, W. \& Grimm, V. (2012). Agent-based modelling: Tools for linking NetLogo and R. Journal of Artificial Societies and Social Simulation, 15(3), 8

Thiele, J. C., Kurth, W. \& Grimm, V. (2014). Facilitating parameter estimation and sensitivity analysis of agentbased models: A cookbook using NetLogo and R. Journal of Artificial Societies and Social Simulation, 17(3), 11

Thomson Reuters (2002). Journal self-citation in the journal citation reports - science edition

Thomson Reuters (2016). ESI category - journal mapping

Van Raan, A. F. J. (2014). Advances in bibliometric analysis: Research performance assessment and science mapping. Bibliometrics. Use and Abuse in the Review of Research Performance, (pp. 17-28)

Watts, D. J. \& Strogatz, S. H. (1998). Collective dynamics of 'small-world' networks. Nature, 393(6684), 440-442

Wellman, M. P. (2014). Putting the agent in agent-based modeling. Autonomous Agents and Multi-Agent Systems, 30(6), 1175-1189

Wilensky, U. (1999). NetLogo. Center for Connected Learning, Northwestern University

Zhang, J., Chen, C. \& Li, J. (2009). Visualizing the intellectual structure with paper-reference matrices. IEEE Transactions on Visualization and Computer Graphics, 15(6), 1153-1160 